\title{
Evaluation of Flowing Salt Irradiation Facilities with High Neutron Flux
}

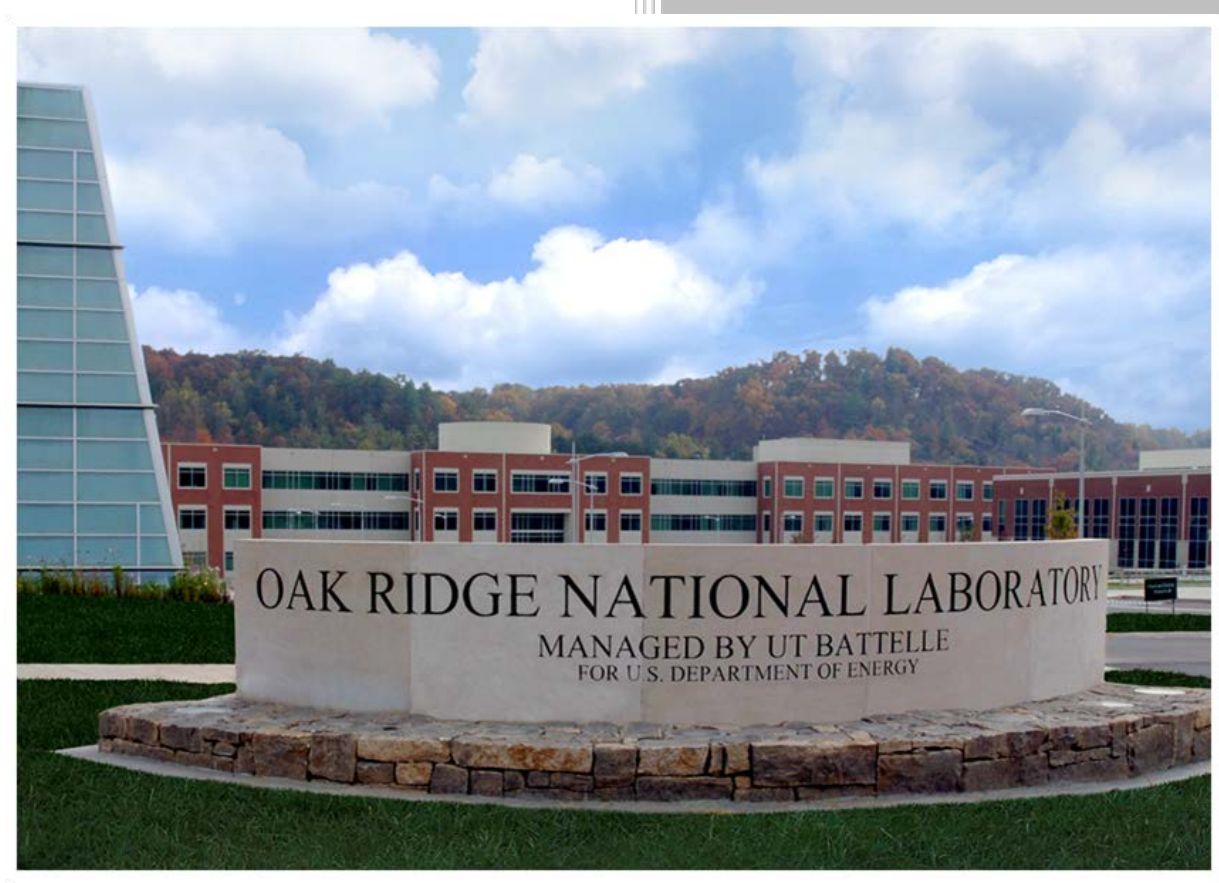

Joel McDuffee Nesrin Cetiner

N. Diane Bull Ezell Lou Qualls

Ken Thoms

August 15, 2018 


\title{
DOCUMENT AVAILABILITY
}

Reports produced after January 1, 1996, are generally available free via US Department of Energy (DOE) SciTech Connect.

\section{Website http://www.osti.gov/scitech/}

Reports produced before January 1, 1996, may be purchased by members of the public from the following source:

\author{
National Technical Information Service \\ 5285 Port Royal Road \\ Springfield, VA 22161 \\ Telephone 703-605-6000 (1-800-553-6847) \\ TDD 703-487-4639 \\ Fax 703-605-6900 \\ E-mail info@ntis.gov \\ Website http://classic.ntis.gov/
}

Reports are available to DOE employees, DOE contractors, Energy Technology Data Exchange representatives, and International Nuclear Information System representatives from the following source:

Office of Scientific and Technical Information

PO Box 62

Oak Ridge, TN 37831

Telephone 865-576-8401

Fax 865-576-5728

E-mail reports@osti.gov

Website http://www.osti.gov/contact.html

This report was prepared as an account of work sponsored by an agency of the United States Government. Neither the United States Government nor any agency thereof, nor any of their employees, makes any warranty, express or implied, or assumes any legal liability or responsibility for the accuracy, completeness, or usefulness of any information, apparatus, product, or process disclosed, or represents that its use would not infringe privately owned rights. Reference herein to any specific commercial product, process, or service by trade name, trademark, manufacturer, or otherwise, does not necessarily constitute or imply its endorsement, recommendation, or favoring by the United States Government or any agency thereof. The views and opinions of authors expressed herein do not necessarily state or reflect those of the United States Government or any agency thereof. 
Reactor and Nuclear Systems Division

\section{Evaluation of Flowing Salt Irradiation Facilities with High Neutron Flux}

Joel McDuffee

Nesrin Cetiner

N. Dianne Bull Ezell

Lou Qualls

Ken Thoms

August 2018

Prepared by

OAK RIDGE NATIONAL LABORATORY

Oak Ridge, TN 37831-6283

managed by

UT-BATTELLE, LLC

for the

US DEPARTMENT OF ENERGY

under contract DE-AC05-00OR22725 



\section{CONTENTS}

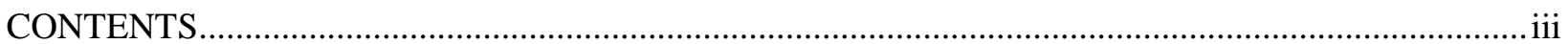

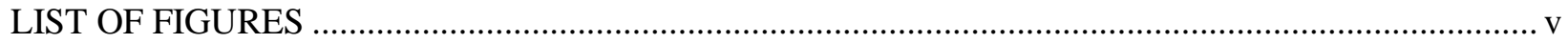

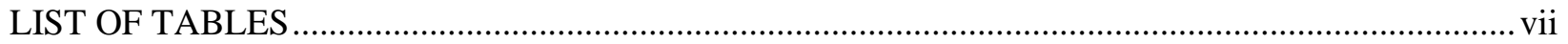

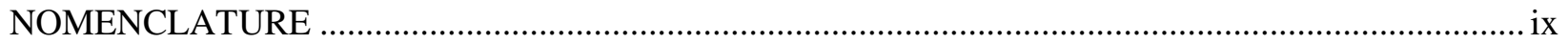

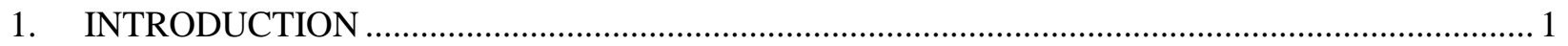

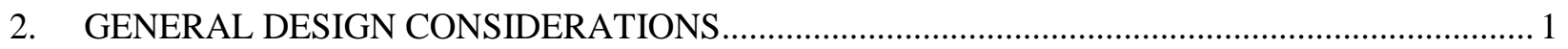

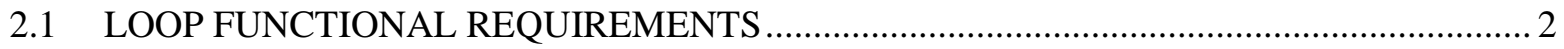

3. IRRADIATION HISTORY FOR MOLTEN SALT IN FLOWING LOOPS ................................ 4

3.1 FORCED-CIRCULATION LOOPS IN THE MTR …....................................................... 4

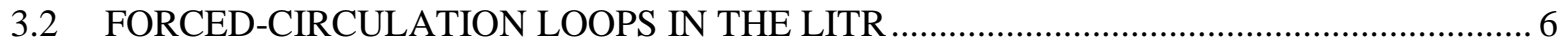

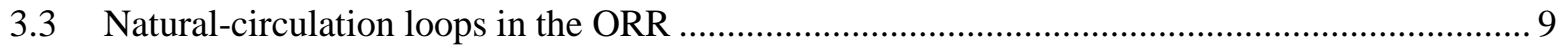

4. SELECTED RESEARCH REACTORS WITH RELEVANT IRRADIATION FACILITIES ........... 13

4.1 DEPARTMENT OF ENERGY NATIONAL LABORATORY REACTORS ....................... 18

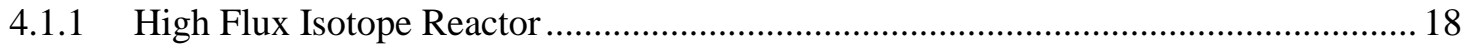

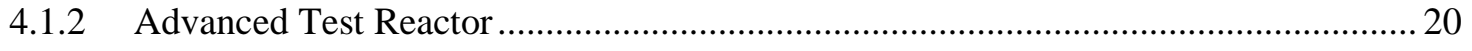

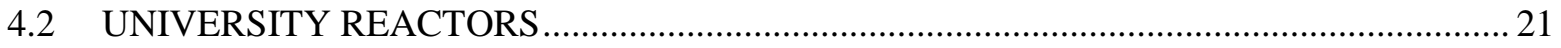

4.2.1 Ohio State University Research Reactor (OSURR) ............................................... 21

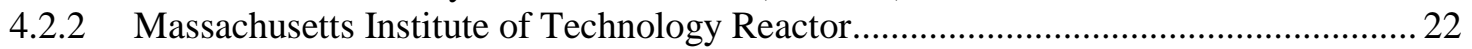

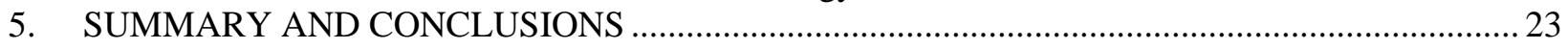

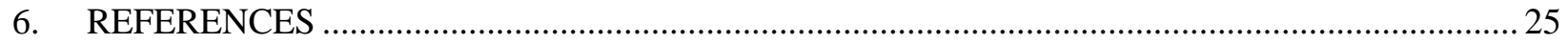





\section{LIST OF FIGURES}

Figure 1. Diagram of molten salt fuel loop irradiated in the MTR.......................................................... 5

Figure 2. Fuel pump used for molten salt fuel loop (fused-salt inpile loop) irradiated in the MTR............ 5

Figure 3. Exploded view of pump used for MTR molten salt fuel loop. ................................................... 6

Figure 4. LITR horizontal forced-convection loop for dynamic corrosion testing of molten

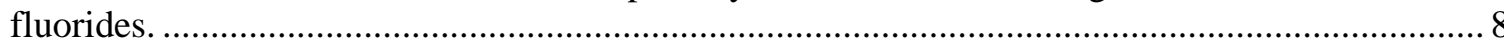

Figure 5. LITR vertical forced-circulation loop for dynamic corrosion testing of molten fluorides............ 9

Figure 6. ORR Molten-Salt Natural Convection Loop 1...................................................................... 10

Figure 7. Cross section of ORR Molten-Salt Loop 2 ….......................................................................... 11

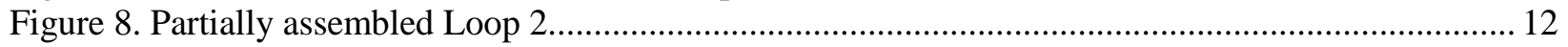

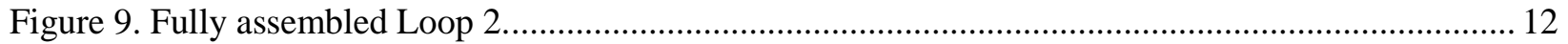

Figure 10. Reactor core fuel plates and primary irradiation facilities..................................................... 18

Figure 11. Characteristics of major irradiation positions in the HFIR ................................................... 19

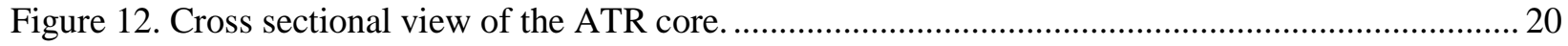

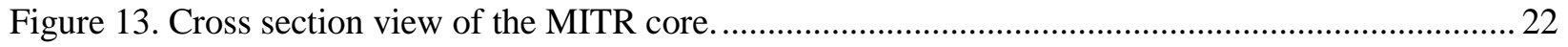





\section{LIST OF TABLES}

Table 1. Summary of Reactor Capabilities for a Molten Salt Flowing Loop Experiment......................... 14

Table 2. Characteristics of irradiation positions in the ATR ................................................................. 21

Table 3. Characteristics of selected irradiation positions in the OSURR ............................................. 22

Table 4. Characteristics of irradiation positions in the MITR ................................................................ 23 



\section{NOMENCLATURE}

$\begin{array}{ll}\text { AIF } & \text { Axial Irradiation Facility } \\ \text { ATR } & \text { Advanced Test Reactor } \\ \text { ASME } & \text { American Society of Mechanical Engineers } \\ \text { CIF } & \text { Central Irradiation Facility } \\ \text { FCF } & \text { Fuel Conditioning Facility } \\ \text { HFEF } & \text { Hot Fuel Examination Facility } \\ \text { HTGR } & \text { High Temperature Gas-cooled Reactor } \\ \text { ID } & \text { inner diameter } \\ \text { LITR } & \text { Low Intensity Test Reactor } \\ \text { MITR } & \text { Massachusetts Institute of Technology Reactor } \\ \text { MS } & \text { Molten salt } \\ \text { MSR } & \text { Molten salt reactor } \\ \text { MSRE } & \text { Molten Salt Reactor Experiment } \\ \text { MTR } & \text { Materials Test Reactor } \\ \text { MURR } & \text { Missouri University Research Reactor } \\ \text { OD } & \text { outer diameter } \\ \text { ORNL } & \text { Oak Ridge National Laboratory } \\ \text { ORR } & \text { Oak Ridge Research Reactor } \\ \text { OSURR } & \text { Ohio State University Research Reactor } \\ \text { PIE } & \text { post-irradiation examination } \\ \text { PIF } & \text { Peripheral Irradiation Facility } \\ \text { PWR } & \text { pressurized water reactor } \\ \text { RB } & \text { removable beryllium } \\ \text { SNM } & \text { special nuclear material } \\ \text { TREAT } & \text { Transient Reactor Test Facility } \\ \text { VXF } & \text { Vertical Experiment Facility }\end{array}$





\begin{abstract}
There is significant current interest in the commercial power industry in developing nuclear reactor concepts using molten salt as a coolant or as a fuel-bearing medium and coolant. The Molten Salt Reactor Experiment (MSRE), which was performed at Oak Ridge National Laboratory from 1964-1969, established the feasibility of this reactor design and performed some of the early work in qualifying appropriate structural materials and coolant salts. However, modern versions of this design often incorporate aspects that are beyond the design basis of the MSRE. For example, some designs intend to operate at a higher temperature, use a different structural material, or a different salt altogether. These new designs will eventually require irradiation testing in a variety of reactors and conditions. This document specifically evaluates the possibilities and requirements associated with the most difficult of these conditions: a flowing salt irradiation under high neutron flux.
\end{abstract}

\title{
1. INTRODUCTION
}

The primary containment of any molten salt reactor (MSR) concept will be exposed to corrosive salt at high temperatures $\left(>650^{\circ} \mathrm{C}\right)$, which is a challenging design issue. Many MSR designs also use dissolved fuel, which introduces fission product-induced corrosion into the challenge. Even the reactor concepts that do not call for dissolved fuel must consider the deleterious effects of dissolved fission products, albeit at lower concentrations, as this factor will certainly be required in a safety basis evaluation of the design.

At the most basic level, under both design and safety-basis conditions, the reactor primary containment and all components internal to the containment should (1) be resistant to salt corrosion, (2) maintain adequate strength under anticipated and off-normal conditions, and (3) be resistant to corrosion induced by entrained fission products. Experiment results will help establish the capability and lifetime of reactor materials and facilitate the decision making of both the designer and the design authority. While much can and should be learned from out-of-pile testing, many of these concerns can only be addressed with irradiation testing.

Irradiation testing must encompass a wide variety of experimental facilities, including static capsules, natural convection loops, and pumped loops under low flux and high flux conditions, as well as appropriate temperature, flow, energy, and chemical composition. This document outlines existing and future capabilities for the most challenging subset of these experimental conditions: irradiation testing in a flowing loop under a high neutron flux.

\section{GENERAL DESIGN CONSIDERATIONS}

A chief design goal for flowing loop experiments is to maintain prototypic coolant temperature, pressure, flow velocity, and chemistry. Transient experiment designs may require the ability to simulate flow or temperature excursions at specific rates over specific timeframes. Historically, this requirement has been met using either external loops or cartridge experiments. In an external loop, a coolant-circulating loop extends from the active irradiation section of the experiment to a facility located outside the reactor vessel. This adjacent facility manages pumping, chemistry control, and heat exchange. A cartridge experiment, in contrast, is a self-contained apparatus in which all action occurs at or near the irradiation location. 
Both experiment designs have significant advantages and disadvantages. Because of its relative size, the external loop typically has fewer design constraints on the coolant flowrate and heat exchange. Design costs are typically lower due to a less challenging environment and because off-the-shelf components are more likely to be available. It is also significantly easier to measure and modify coolant chemistry. While some of these factors are advantages to the experiment designer, they can also be disadvantages to the reactor operator, who must allocate a large floor space to accommodate pumps, heat exchangers, chemistry control, etc. Operators also must (1) be willing and able to handle potentially highly-activated coolant flows (2) be capable of anticipating breaches of piping in the adjacent laboratory, and (3) have procedures in place to manage clean up.

A cartridge experiment is more limited in capability. Space constraints require miniaturization of key components such as pumps, which may not be commercially available, and limit the available flow rates and/or pipe size/salt quantity. The reactor's primary coolant becomes the ultimate heat sink, so the total experiment heat load is limited by the coolant's ability to remove the heat safely under off-normal conditions. Chemistry control is still possible via small gauge tubing, but monitoring must be designed within the cartridge. One of the most significant design challenges is the inability to use organic compound-based components, such as o-rings, due to the proximity to high gamma flux in the core region. Organic compounds generally have low radiation resistance to gamma radiation and would quickly degrade under flux regimes representative of most applicable irradiation facilities. This is a severe limiting factor, especially for pumps, most of which require o-ring seals for their operation.

Despite these disadvantages, a cartridge experiment design will usually be the best choice for molten salt flowing loop experiments for two basic reasons: (1) lack of infrastructure in existing and planned high-flux research reactors and (2) the difficulty associated with preventing salt solidification while it travels the long distance from the core to the adjacent laboratory-typically tens of meters - and back. The latter concern also has safety implications since a loss of heating would block the flow and leave the in-core section static, with no room for thermal expansion. While some existing research reactors (e.g., the Advanced Test Reactor [ATR] at Idaho National Laboratory) have external flow loops, these loops are designed for light water reactor conditions. A similar molten salt loop would necessitate a completely new design and would have different safety conditions.

The use of cartridge experiments is not without precedent. As discussed in Section 3, this type of experiment was used in preparation for the MSRE. Also, the Transient Reactor Test Facility (TREAT) reactor design team has successfully designed a sodium cartridge loop experiment [1]. While cartridge experiments are complex and challenging, the overall advantages in safety, facility impact, and cost are decisive.

\subsection{LOOP FUNCTIONAL REQUIREMENTS}

There are key parameters and design conditions that must be met in an experiment. The following is a short list of some key points to consider in any flowing loop salt design.

- Pressure vessel. The primary experiment containment (i.e., the outermost experiment structure in contact with the reactor's primary coolant) typically has to meet the American Society of Mechanical Engineers (ASME) requirements for a pressure vessel during normal and off-normal conditions. 
- Internal heating. It will be necessary to have the loop molten and flowing before reactor startup and after reactor shutdown. The sudden insertion of heat during reactor startup, while the experiment is still solid, would likely lead to excessive containment stress due to differential thermal expansion between the salt and the containment. Even without radiation, the intermediate, partially melted phase would likely damage the pump. Finally, some salts are known to disassociate when exposed to radiation at low temperature. For example, $\mathrm{FLiBe}$ has been shown to generate $\mathrm{F}_{2}$ gas when irradiated at temperatures below about $80^{\circ} \mathrm{C}$.

- Gap insulation. Currently, all steady-state high-flux research reactors are water cooled, with water coolant temperatures below $100^{\circ} \mathrm{C}$. This feature requires a gas or vacuum gas gap between the primary outer containment and the inner containment, which contains the salt. The insulation value of the gap can be set by the thickness of the gap and by the effective thermal conductivity of the gas. The effective thermal conductivity can be modified during irradiation by either mixing two gases with different thermal conductivities (e.g., helium and argon) or by pulling a vacuum in the gas space.

- Containment considerations. As mentioned previously, organic compound based parts, such as o-rings, cannot withstand the intense gamma irradiation associated with high neutron flux reactors for extended periods of time. Experiments must typically be sealed by welding, which may require weld procedure development. For the outer containment, the welds must meet pressure vessel standards.

- Utilities. The necessary utilities may vary by experiment, but they will typically include electrical power supply for heaters, pumps, and instrumentation; gas supply for temperature and pressure control; a gas effluent system for fission product or off-gas analysis; instrumentation leads as required for the experiment; and chemistry control supply and return.

- Flexible leads. The utilities must be delivered to the experiment through many meters of small gauge tubing. The leads are typically bundled together inside a flexible container tube. All the leads must be flexible enough to be moved into and out of position between cycles to allow for reactor maintenance and refueling.

- Seismic design. The top end of a cartridge experiment is usually of larger diameter and may cantilever out of the core some distance. However, the experiment designer must consider seismic loading on the assembly to make sure it can withstand any seismic incident that the reactor itself can withstand.

- Pump design. The pump design may be the most difficult aspect of the flowing loop. The pump must be capable of moving molten salt at $650-800^{\circ} \mathrm{C}$ without significant operational degradation over the irradiation duration. Unless the pump is designed to be far removed from the core region (which may introduce cooling issues), the pump must be sealed without organic o-rings. Since it will be sealed inside the containment, the pump mechanism should be as simple as possible to ensure reliability throughout operation. Finally, the pump must fit inside the inner containment piping, which may only be $5-10 \mathrm{~cm}$ in diameter. 


\section{IRRADIATION HISTORY FOR MOLTEN SALT IN FLOWING LOOPS}

\subsection{FORCED-CIRCULATION LOOPS IN THE MTR}

A series of forced-circulation loops were designed and built by Oak Ridge National Laboratory (ORNL) in the late 1950s to obtain corrosion data applicable to molten-salt fueled reactors. These loops were irradiated in a horizontal beam hole (HB-3) in the Materials Testing Reactor (MTR) in Idaho and were designated either ORNL-20 or ORNL-MTR-44 in-pile loops.

Two salt mixtures and two container materials were tested in these loops. The first six loops contained $\mathrm{NaF}_{-} \mathrm{ZrF}_{4}-\mathrm{UF}_{4}$ in a loop made of Inconel, and the last two contained $\mathrm{Li}^{7} \mathrm{~F}-\mathrm{BeF}_{2}-\mathrm{UF}_{4}$ in a loop of INOR-8. The general configuration of the loop design is shown in Figure 1. The loop test section that was brought near the reactor's face was made of a hairpin-shaped length of $1 / 8$-inch schedule 40 pipe (inner diameter [ID] $=0.269$ in., outer diameter [OD] $=0.407$ in.). The entire loop was contained in a 5.5-inch OD water-cooled double-walled jacket, which served both as an enclosure for double containment and as a heat sink. The overall assembly was $150 \mathrm{in.} \mathrm{long}$ and was divided into three hermetically sealed compartments for protection against the release of fission gas to the atmosphere.

Of the loops that ran (loops 3, 4, 6, 7, and 8), the maximum operating temperature was from 700$870^{\circ} \mathrm{C}$, and the thermal neutron flux in the fuel was $6 \cdot 10^{13} \mathrm{n} / \mathrm{cm}^{2}$-sec.

A regenerative turbine-type pump was designed specifically for these loops. Significant effort was expended on the pump design, and a modified version (Mark II) was developed for loops 6 through 8 . Out-of-reactor testing was conducted on a prototype of the modified version. This testing included more than 1,100 hours of testing at temperatures that were $25-45^{\circ} \mathrm{C}$ higher than the in-reactor loop pump would see. A cross section of the latest pump used in the loops is shown in Figure 2, and a photograph of the pump's components is shown in Figure 3. 


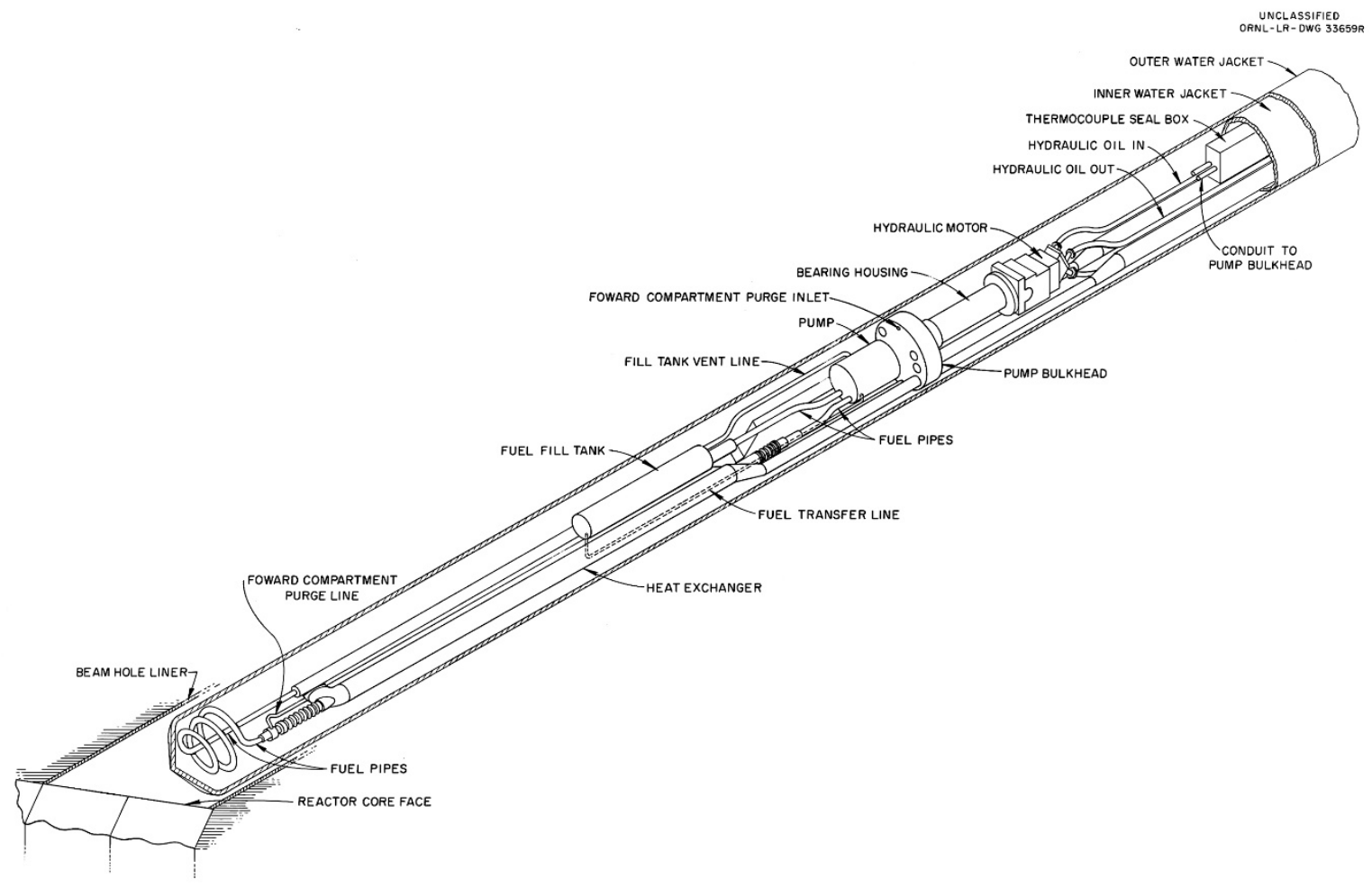

Figure 1. Diagram of molten salt fuel loop irradiated in the MTR.

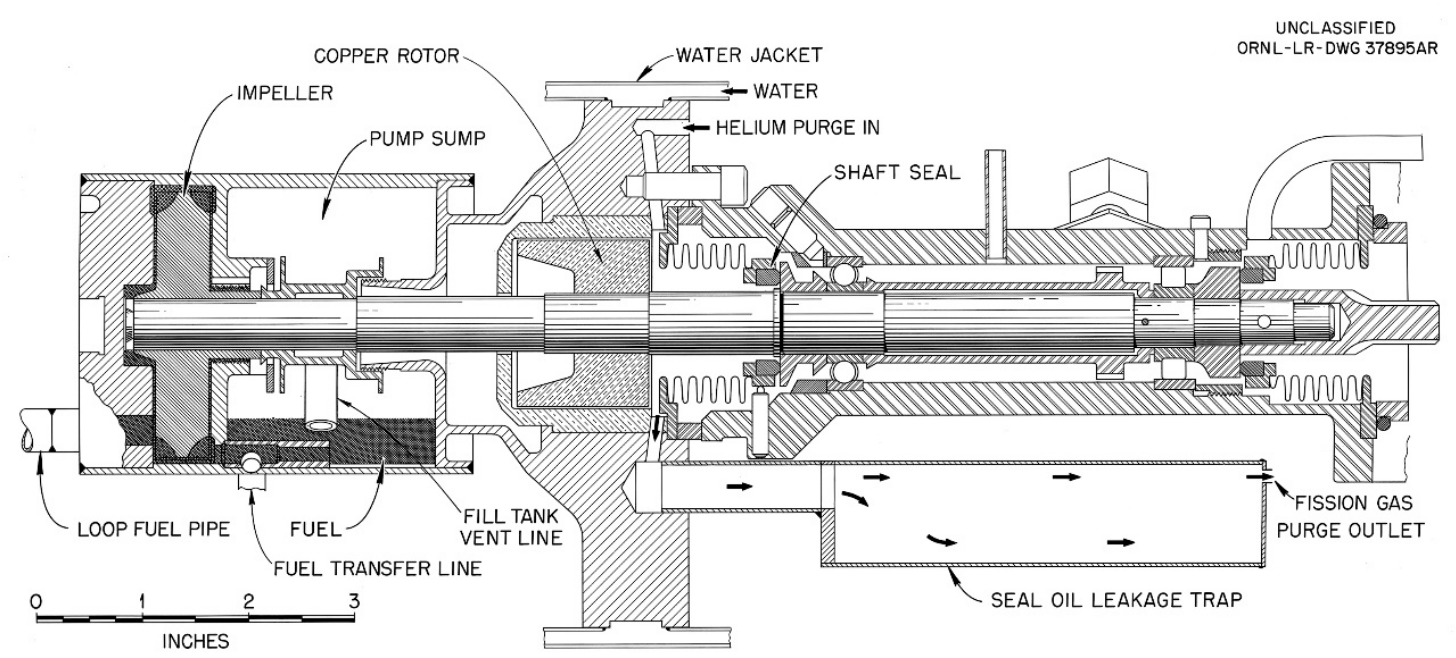

Figure 2. Fuel pump used for molten salt fuel loop (fused-salt inpile loop) irradiated in the MTR. 


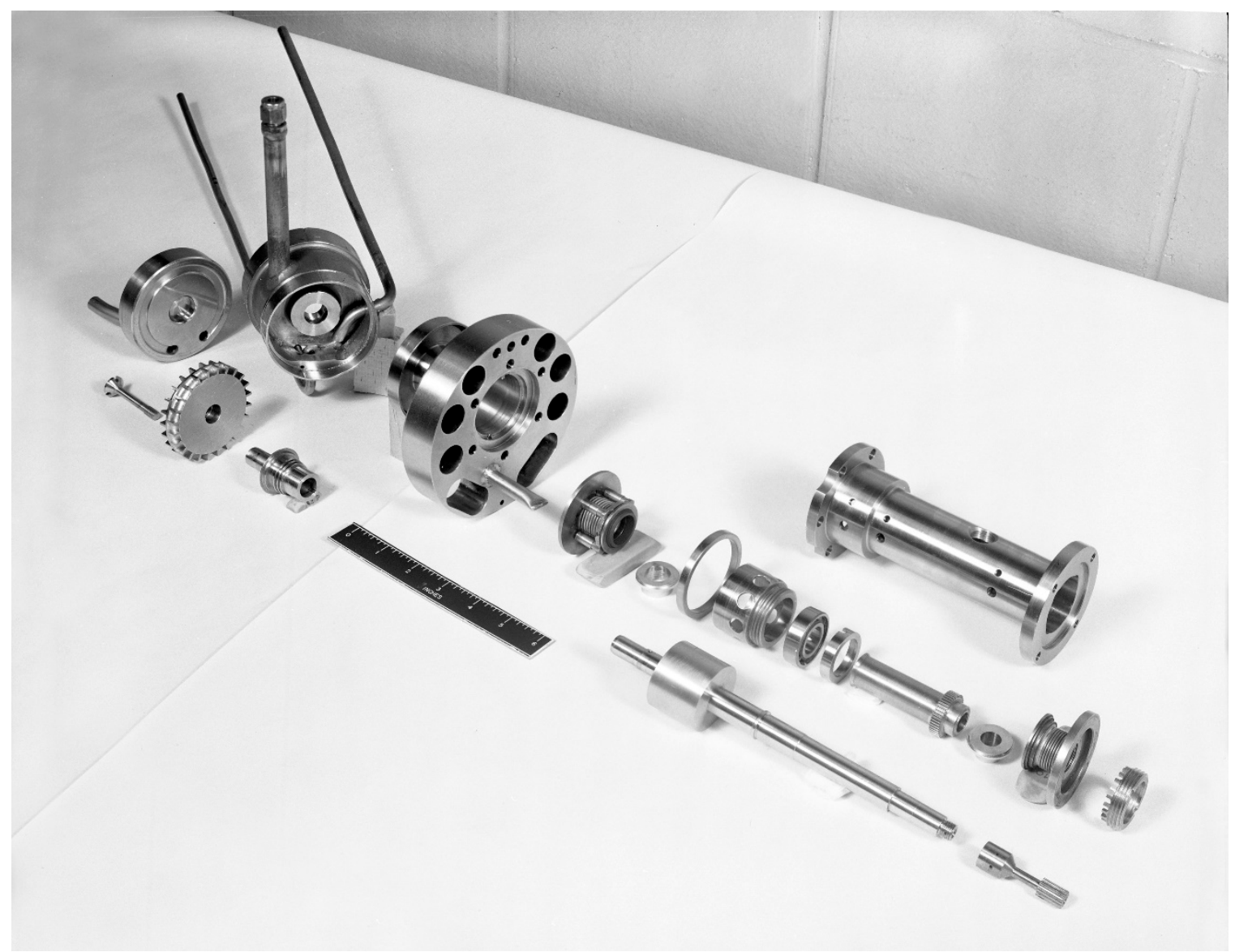

Figure 3. Exploded view of pump used for MTR molten salt fuel loop.

Numerous reference documents were found describing the evolution of these loops from their early design documents to materials covering problems experienced in assembly and operation of the loops. ORNL-2387 [2] discusses flux measurement techniques for beam hole HB-3 at the MTR, a bench test mockup of the first loop, design and testing of the pump, and instrumentation for the loop. ORNL-2221 [3] describes problems with Loop 6, which include increasing the capacity of the loop heat exchanger, as well as problems and modifications to the pump. A memorandum on molten salt breeder reactors (ORNL-CF-58-10-64) [4] was prepared to document the planned operating conditions of Loop 7. It describes the performance characteristics of the Mark III pump and the heat exchanger. Some of the most interesting information in this document appears in Appendix 1, which describes the problems encountered with the first 6 loops and the proposed modifications to alleviate those problems. Trauger and Conlin [5] provide the most comprehensive description of the loop design. These materials list the operating conditions for the five loops that ran (loops 3, 4, 6, 7, and 8), describe the instrumentation and control system, and describe the installation of all the auxiliary equipment at the MTR that was necessary to run the loops. ORNL-3574 [6] covers much of the same information but has additional photos covering the assembly of the loops.

\subsection{FORCED-CIRCULATION LOOPS IN THE LITR}

A series of forced-circulation molten salt loops were operated in the Low Intensity Test Reactor (LITR) at ORNL in the late 1950s, but not much information has been found about the detail design or operating experience. Keilholtz, Morgan, and Browning reported that a "large loop was 
operated in a horizontal beam-hole of the LITR. The pump for circulating the fuel in this loop was placed outside the reactor shield. A smaller loop was operated in a vertical position in the lattice of the LITR, its pump mounted just above the lattice. Drawings of the LITR horizontal and vertical loops are shown in Figure 4 and Figure 5.

ORNL-2221 [3] describes the pump used in the vertical loops and states that the $8^{\text {th }}$ loop was being assembled, indicating that at least 8 vertical loops were operated in the LITR. 


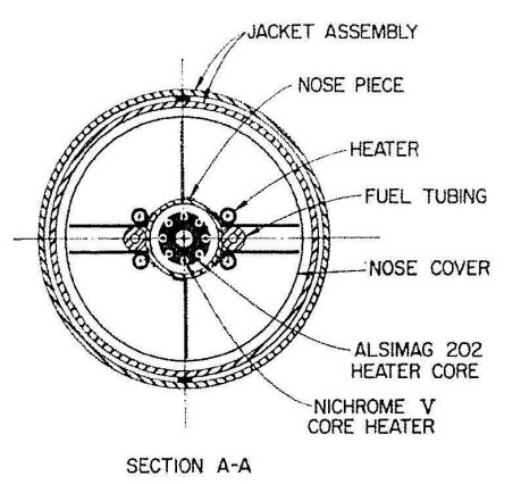

SECTION A-A
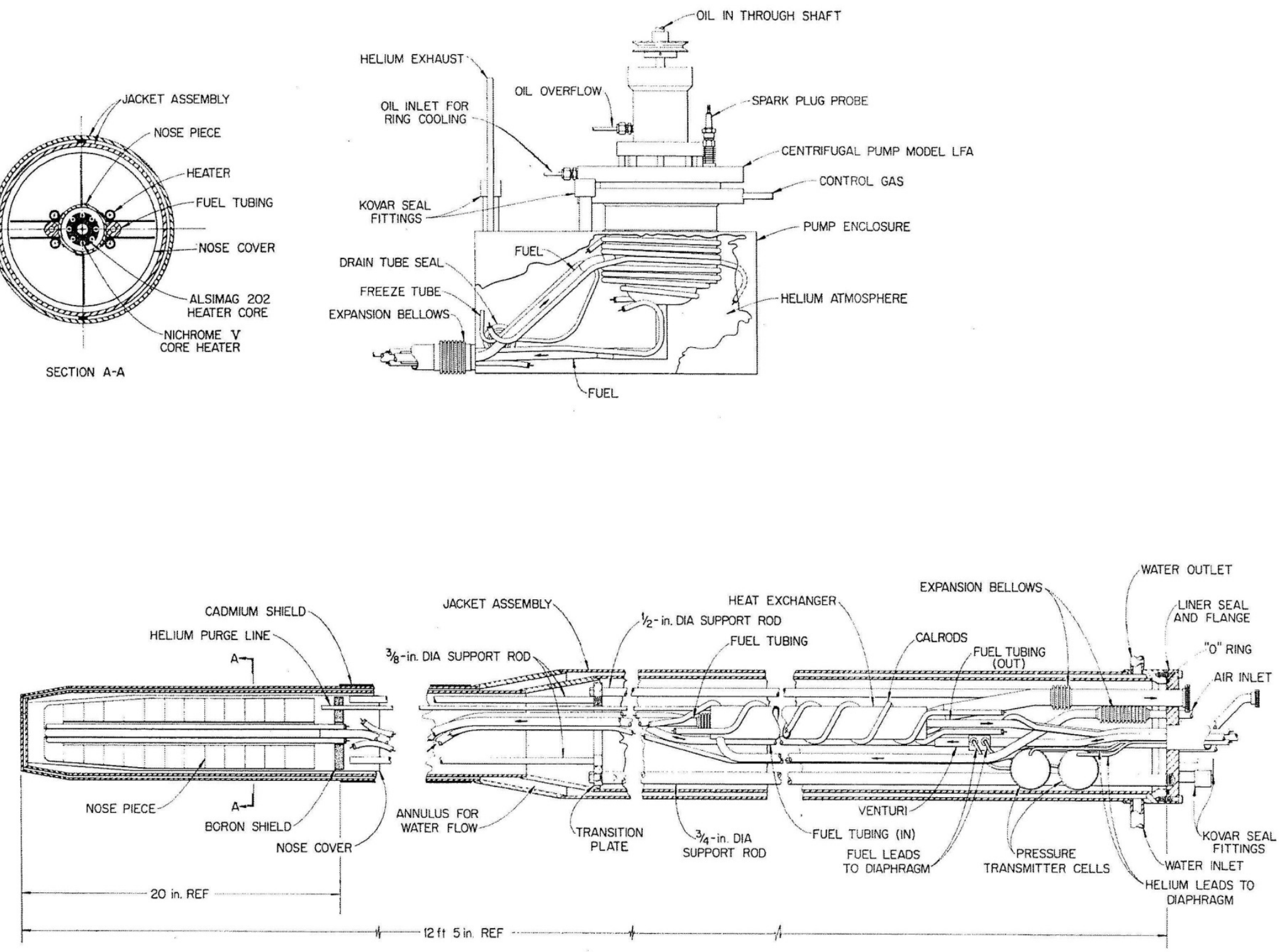

Figure 4. LITR horizontal forced-convection loop for dynamic corrosion testing of molten fluorides. 


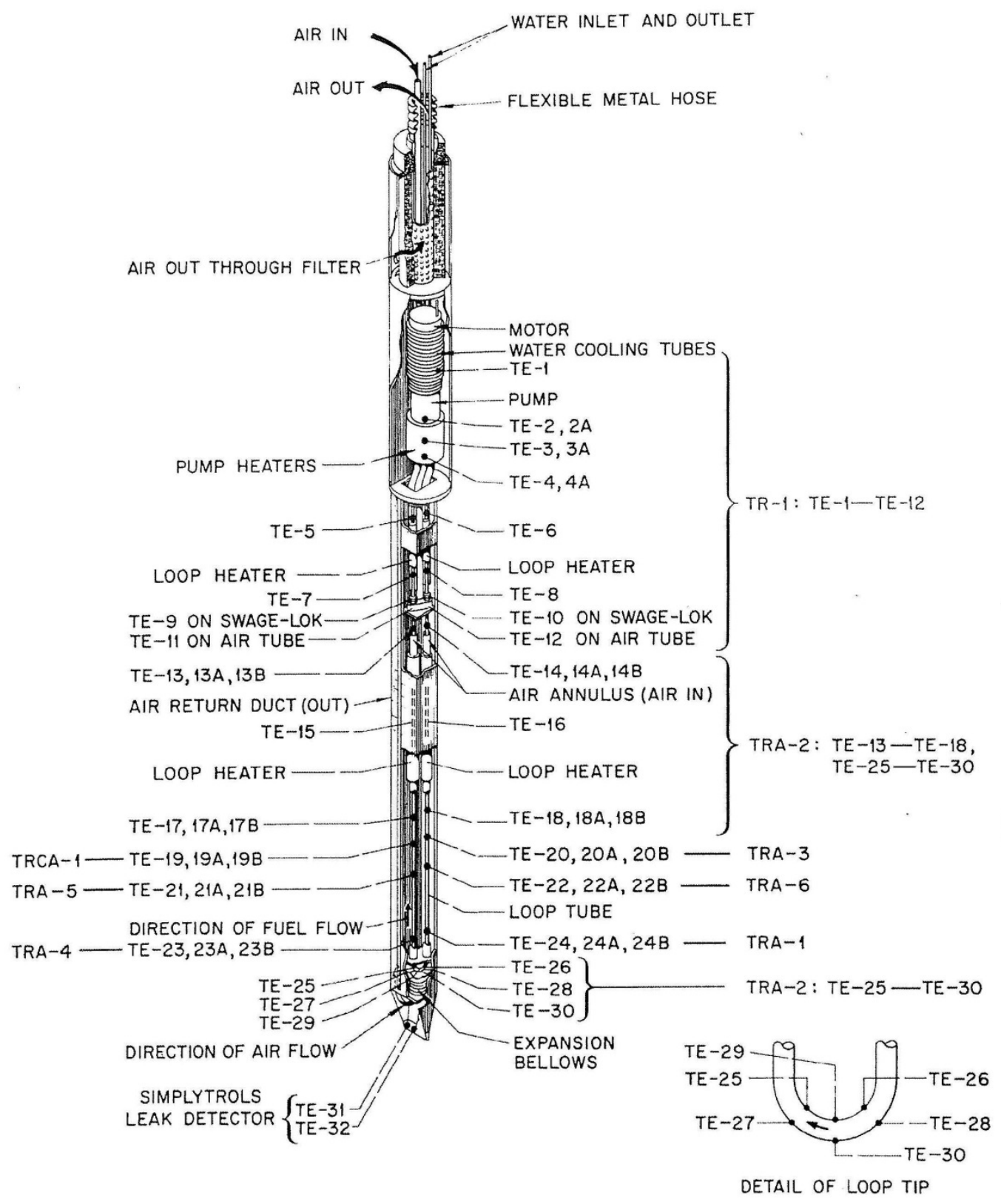

Figure 5. LITR vertical forced-circulation loop for dynamic corrosion testing of molten fluorides.

\subsection{NATURAL-CIRCULATION LOOPS IN THE ORR}

Two natural-circulation molten salt loops were operated in a beam hole (HN-1) of the Oak Ridge Research Reactor (ORR)[7]. The loops were built to study the compatibility of Hastelloy $\mathrm{N}$ and graphite with the fuel salt, and to study fuel salt stability and fission product chemistry. The main body of the loop was fabricated of 2-inch schedule-40 Hastelloy N (INOR-8) pipe, which contained a graphite core. The graphite core had eight $1 / 4$-inch holes which served as fuel passages. A gas separation tank served as a salt reservoir and provided a liquid-vapor interface. A return line from the gas separation tank to the bottom of the graphite core completed the loop circuit. Electric heaters and cooling coils, imbedded in a sprayed nickel matrix, surrounded the core section, gas separation tank, and return line to provide temperature 
control and to maintain the thermal gradients necessary to induce convective flow. A drawing of the Loop 1 assembly is shown in Figure 6.

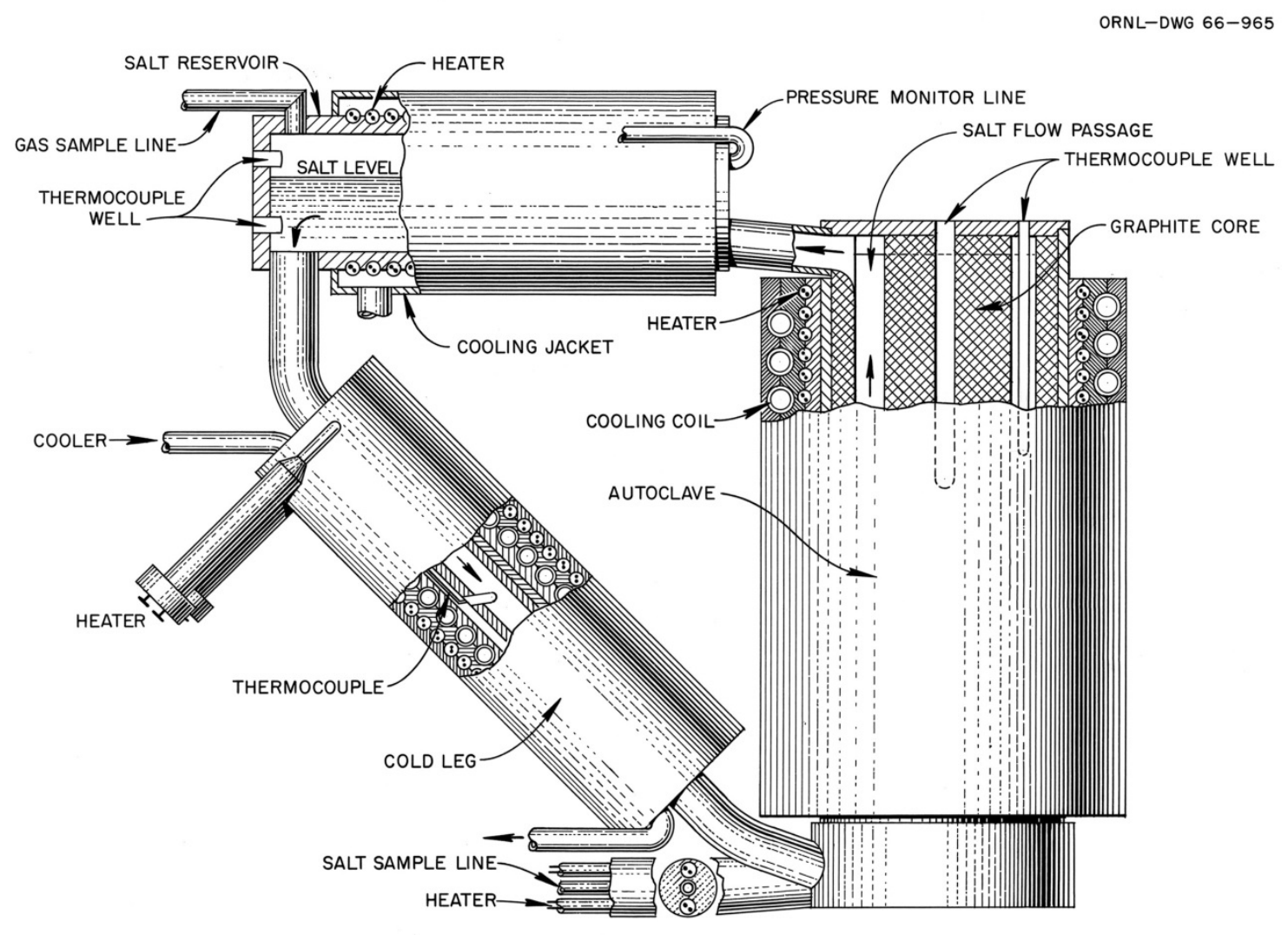

Figure 6. ORR Molten-Salt Natural Convection Loop 1.

Loop 1 operated for 1,025 hours at $30 \mathrm{MW}$ reactor power with solvent salt $\left(\mathrm{Li}^{7} \mathrm{~F}-\mathrm{BeF}_{2}-\mathrm{ZrF}_{4}\right.$ [64.7-30.15.2 mole \%]) and an additional 289 hrs at $30 \mathrm{MW}$ with fuel salt $\left(\mathrm{Li}^{7} \mathrm{~F}-\mathrm{BeF}_{2}-\mathrm{ZrF}_{4}-\mathrm{UF}_{4}\right.$ [65.16-28.57-4.901.36 mole \%]. Operation was terminated after high radiation levels were observed in the charcoal trap in the loop container off-gas line, indicating fission-product leakage from the loop. During post-irradiation examination (PIE) it was determined that fuel salt had leaked at a break in the salt sample line near the location where it was attached to the loop core section. There were numerous other leaks that caused additional operating problems with Loop 1.

While Loop 2 was essentially identical to the first loop, several design modifications were made to eliminate the problems experienced in the first loop. These modifications are described in detail on pages 18 and 20 of Reference 8. A cross-section view of Loop 2, which also shows thermocouple locations, is shown in Figure 7. A photograph of the partially assembled Loop 2 is shown in Figure 8, and the fully assembled loop is shown in Figure 9. The solvent and fuel salts used in Loop 2 were the same compositions as Loop 1, except for a slightly higher $\mathrm{UF}_{4}$ concentration in the fuel salt. Loop 2 operated for $341 \mathrm{hrs}$. at $30 \mathrm{MW}$ with the solvent salt, and 1,369 hrs at $30 \mathrm{MW}$ reactor power with the fuel salt. Once again, operation was terminated when high radiation levels were observed on the charcoal trap in the loop container sweep gas line. During PIE, a gas leak was observed in the core outlet tube where it was attached to the core body. Post-test analysis of this failure concluded that it was probably caused by excessive stresses resulting from differential thermal expansion of the loop components. 


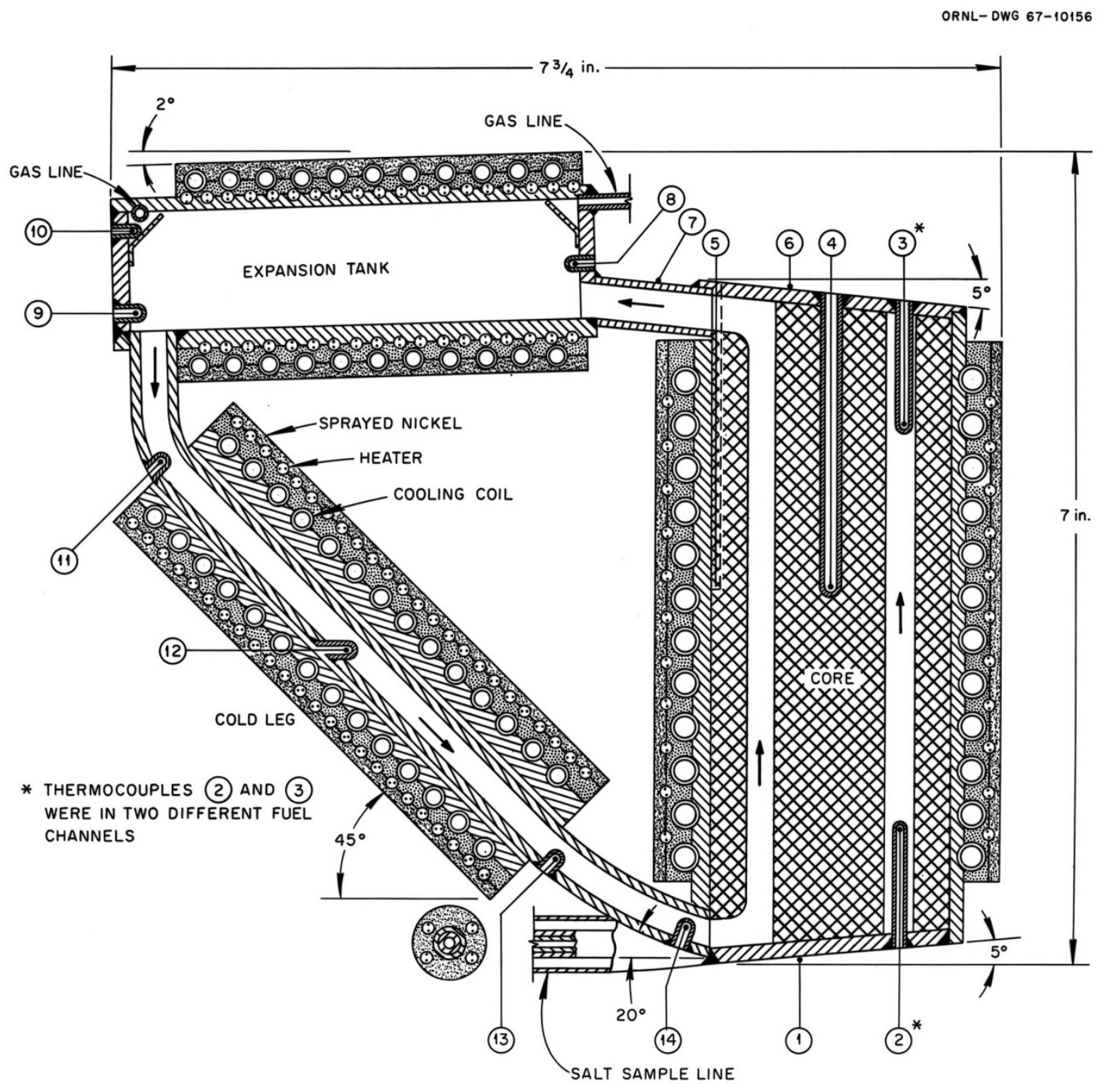

Figure 7. Cross section of ORR Molten-Salt Loop 2. 


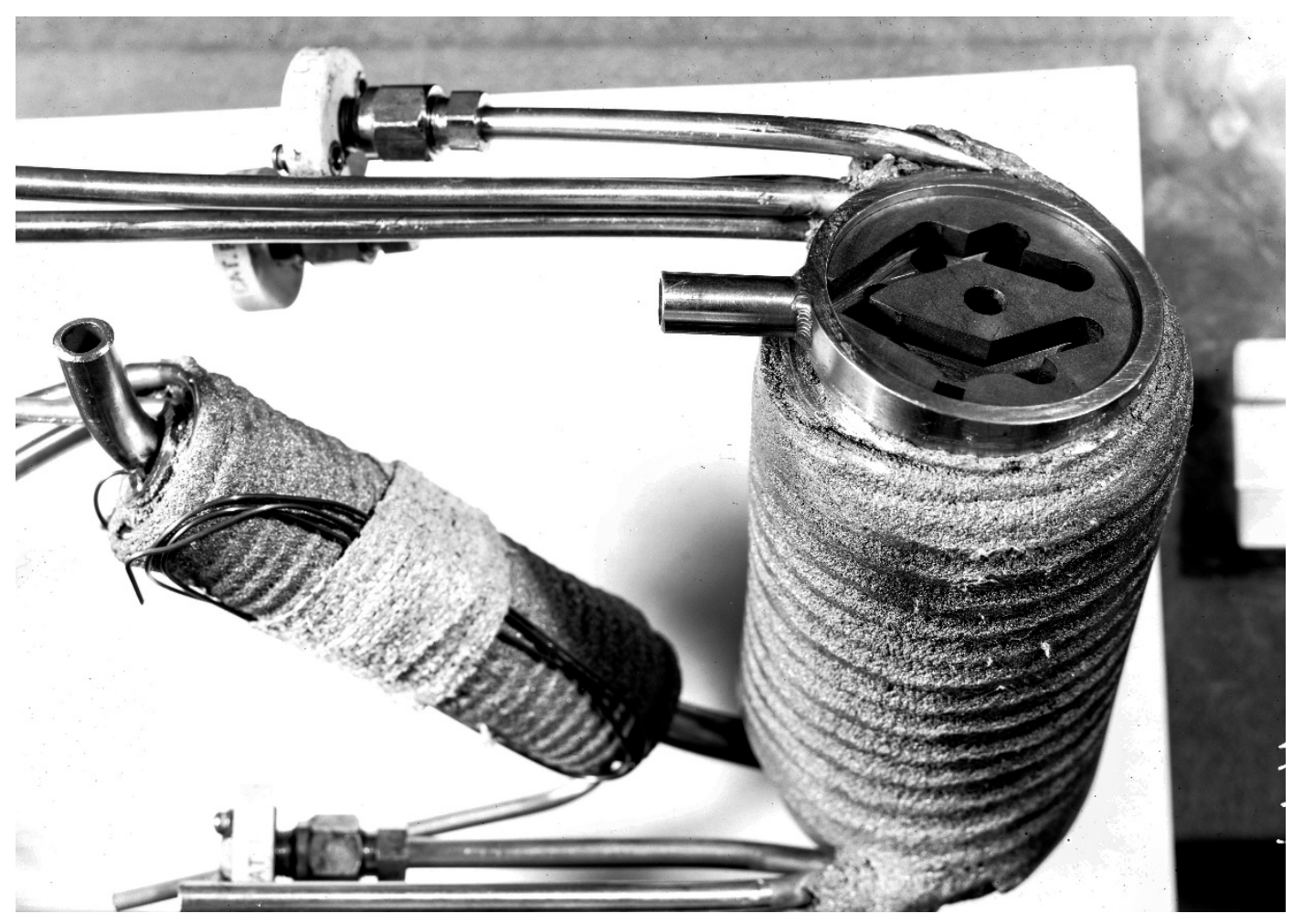

Figure 8. Partially assembled Loop 2.

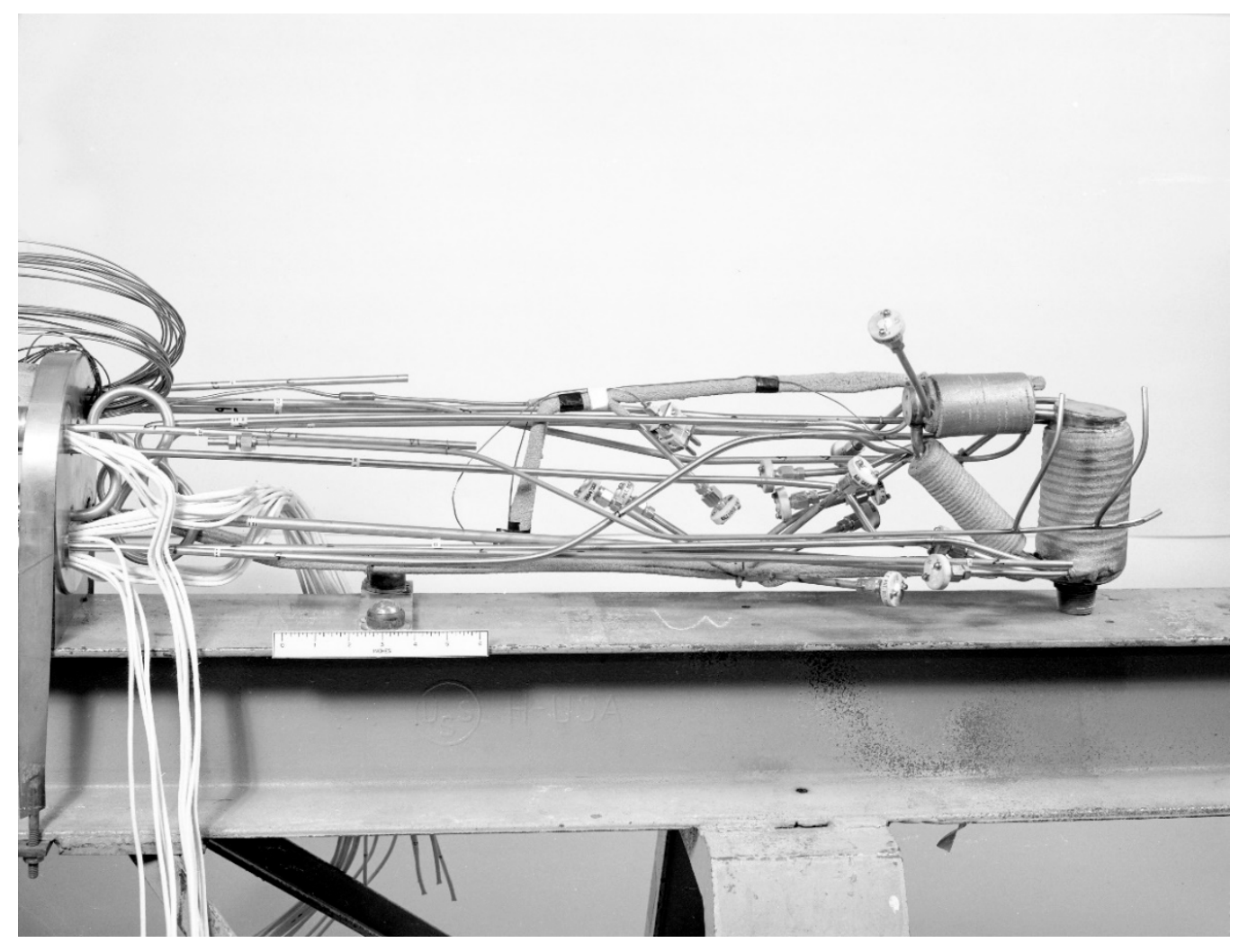

Figure 9. Fully assembled Loop 2. 


\section{SELECTED RESEARCH REACTORS WITH RELEVANT IRRADIATION FACILITIES}

Table 1 summarizes the major characteristics of materials research reactors in the United States capable of supporting a flowing loop system. 
Table 1. Summary of reactor capabilities for a molten salt flowing loop experiment

\begin{tabular}{|c|c|c|c|c|c|c|}
\hline & $\begin{array}{l}\text { High Flux Isotope } \\
\text { Reactor (HFIR) }\end{array}$ & $\begin{array}{c}\text { Advanced Test Reactor } \\
\text { (ATR) }\end{array}$ & MIT Reactor (MITR) & $\begin{array}{c}\text { University of } \\
\text { Missouri Research } \\
\text { Reactor (MURR) }\end{array}$ & $\begin{array}{c}\text { The Ohio State } \\
\text { University Research } \\
\text { Reactor (OSURR) }\end{array}$ & $\begin{array}{c}\text { Penn State Breazeale } \\
\text { Nuclear Reactor }\end{array}$ \\
\hline Management & $\begin{array}{l}\text { Oak Ridge National } \\
\text { Laboratory }\end{array}$ & $\begin{array}{l}\text { Idaho National } \\
\text { Laboratory }\end{array}$ & $\begin{array}{l}\text { Massachusetts } \\
\text { Institute of } \\
\text { Technology }\end{array}$ & University of Missouri & $\begin{array}{l}\text { The Ohio State } \\
\text { University }\end{array}$ & Penn State University \\
\hline City & Oak Ridge, TN & Idaho Falls, ID & Cambridge, MA & Columbia, MO & Columbus, $\mathrm{OH}$ & University Park, PA \\
\hline Reactor type & PWR in pool & PWR in pool & $\begin{array}{l}\text { Heavy Water } \\
\text { Reflected }\end{array}$ & Tank & Pool & TRIGA \\
\hline $\begin{array}{l}\text { Maximum } \\
\text { thermal flux } \\
\left(\mathbf{x 1 0}{ }^{14}\right. \\
\text { n/cm².s })\end{array}$ & 21 & $0.17-1.9$ & 0.36 & 4 & 0.1 & $\begin{array}{l}\text { Up to } 0.33 \\
\text { (central thimble) }\end{array}$ \\
\hline $\begin{array}{l}\text { Maximum } \\
\text { fast flux } \\
\left(\times 10^{14}\right. \\
\left.\mathrm{n} / \mathrm{cm}^{2} \cdot \mathrm{s}\right)\end{array}$ & 11 & $0.013-1.7$ & 1.2 & 0.7 & 0.07 & $\begin{array}{l}\text { Up to } 0.16 \\
\text { (central thimble) }\end{array}$ \\
\hline $\begin{array}{l}\text { Coolant inlet } \\
\text { temperature } \\
\left({ }^{\circ} \mathrm{C}\right)\end{array}$ & 50 & 52 & 42 & 50 & n/a (dry facility) & $25-35$ \\
\hline $\begin{array}{l}\text { Operating } \\
\text { pressure } \\
(\mathrm{MPa})\end{array}$ & 3.3 & 2.5 & 0.1 & $\begin{array}{l}0.176 \mathrm{MPa}(25.5 \mathrm{psi} \text { at } \\
25 \text { feet underwater) }\end{array}$ & 0.1 & $\begin{array}{l}\text { No pressure boundary; } \\
\text { open pool reactor }\end{array}$ \\
\hline $\begin{array}{l}\text { Experiment } \\
\text { facility } \\
\text { diameter } \\
(\mathbf{m m})\end{array}$ & $16-69$ & $16-127$ & 45.7 & $\begin{array}{l}\text { Depends on the } \\
\text { experiment (willing to } \\
\text { customize for } \\
\text { collaborators' needs) }\end{array}$ & $\begin{array}{l}\text { 10-inch dry tube; } 7 \text {-inch } \\
\text { dry tube, } 2.4 \text {-inch dry } \\
\text { tubes (2), 1.3-inch dry } \\
\text { tube }\end{array}$ & $\begin{array}{l}\text { Central thimble: } 32 \mathrm{~mm} \\
\text { (other facilities are } \\
\text { available up to } 100 \mathrm{~mm} \\
\text { with lower flux limits) }\end{array}$ \\
\hline
\end{tabular}


Table 1. Summary of reactor capabilities for a molten salt flowing loop experiment

\begin{tabular}{|c|c|c|c|c|c|c|}
\hline & $\begin{array}{l}\text { High Flux Isotope } \\
\text { Reactor (HFIR) }\end{array}$ & $\begin{array}{c}\text { Advanced Test Reactor } \\
\text { (ATR) }\end{array}$ & MIT Reactor (MITR) & $\begin{array}{c}\text { University of } \\
\text { Missouri Research } \\
\text { Reactor (MURR) }\end{array}$ & $\begin{array}{c}\text { The Ohio State } \\
\text { University Research } \\
\text { Reactor (OSURR) }\end{array}$ & $\begin{array}{l}\text { Penn State Breazeale } \\
\text { Nuclear Reactor }\end{array}$ \\
\hline $\begin{array}{l}\text { Experiment } \\
\text { active length } \\
(\mathrm{mm})\end{array}$ & 508 & 1,220 & 560 & 765 & 380 & $\begin{array}{l}\text { N/A, fuel length is } 380 \\
\text { mm (experiments } \\
>75 \text { mm will have non- } \\
\text { uniform axial flux) }\end{array}$ \\
\hline $\begin{array}{l}\text { Experiment } \\
\text { cabling/rack } \\
\text { installation }\end{array}$ & $\begin{array}{l}\text { Instrument leads exit } \\
\text { through the top of a } \\
\text { capsule. Cables run } \\
\text { out of the reactor } \\
\text { vessel and into an } \\
\text { adjacent laboratory. }\end{array}$ & $\begin{array}{l}\text { Instrument leads exit } \\
\text { through the top of a } \\
\text { capsule. Cables run out } \\
\text { of the vessel and into } \\
\text { experiment cubicles } \\
\text { below the reactor } \\
\text { enclosure }\end{array}$ & $\begin{array}{l}\text { MIT-NRL will work } \\
\text { with users on } \\
\text { electronics and cabling } \\
\text { for lead-out } \\
\text { experiments }\end{array}$ & $\begin{array}{l}\text { Depends on the type, } \\
\text { size, and space } \\
\text { availability }\end{array}$ & $\begin{array}{l}30-35 \text { feet of cabling to } \\
\text { standalone equipment } \\
\text { (example, just installed } \\
\text { at the top of the storage } \\
\text { pool and did not have to } \\
\text { conform to racks) }\end{array}$ & $\begin{array}{l}\text { Experiments need to be } \\
\text { reviewed for safety. } \\
\text { Electronics must not } \\
\text { interfere with reactor } \\
\text { control system }\end{array}$ \\
\hline $\begin{array}{l}\text { Typical } \\
\text { operating } \\
\text { fraction }\end{array}$ & $46 \%$ & $70 \%$ & $\begin{array}{l}60 \% \text {; operating } 24 / 7 \text {; } \\
\text { each cycle lasts } 8-10 \\
\text { weeks. Can reduce } \\
\text { cycle length as } \\
\text { necessary }\end{array}$ & $\begin{array}{l}\text { Operates at 10MW } 24 \\
\text { hours per day } 6.5 \text { days } \\
\text { per week }\end{array}$ & $\begin{array}{l}\text { On demand, first shift } \\
\text { only }\end{array}$ & $\begin{array}{l}\text { Reactor operations are on } \\
\text { demand, typically 4-6 } \\
\text { hours/day }\end{array}$ \\
\hline $\begin{array}{l}\text { Salt } \\
\text { restrictions }\end{array}$ & $\begin{array}{l}\text { Nothing is explicitly } \\
\text { forbidden. All items } \\
\text { introduced into the } \\
\text { core are subject to } \\
\text { analysis of reactivity } \\
\text { and thermo- } \\
\text { mechanical } \\
\text { performance to } \\
\text { determine if the safety } \\
\text { limits are challenged. }\end{array}$ & $\begin{array}{l}\text { Nothing is explicitly } \\
\text { forbidden. All items } \\
\text { introduced into the core } \\
\text { are subject to analysis of } \\
\text { reactivity and thermo- } \\
\text { mechanical performance } \\
\text { to determine if the safety } \\
\text { limits are challenged. }\end{array}$ & $\begin{array}{l}\text { FLiBe salt irradiations } \\
\text { can performed in } \\
\text { MITR core at } 700^{\circ} \mathrm{C} \text {. }\end{array}$ & $\begin{array}{l}\text { Yes, depending on } \\
\text { experiment }\end{array}$ & $\begin{array}{l}\text { Double encapsulation } \\
\text { would be required for } \\
\text { corrosive materials }\end{array}$ & No restrictions \\
\hline
\end{tabular}


Table 1. Summary of reactor capabilities for a molten salt flowing loop experiment

\begin{tabular}{|c|c|c|c|c|c|c|}
\hline & $\begin{array}{l}\text { High Flux Isotope } \\
\text { Reactor (HFIR) }\end{array}$ & $\begin{array}{c}\text { Advanced Test Reactor } \\
\text { (ATR) }\end{array}$ & MIT Reactor (MITR) & $\begin{array}{c}\text { University of } \\
\text { Missouri Research } \\
\text { Reactor (MURR) }\end{array}$ & $\begin{array}{c}\text { The Ohio State } \\
\text { University Research } \\
\text { Reactor (OSURR) }\end{array}$ & $\begin{array}{c}\text { Penn State Breazeale } \\
\text { Nuclear Reactor }\end{array}$ \\
\hline $\begin{array}{l}\text { Fuel } \\
\text { restrictions }\end{array}$ & $\begin{array}{l}\text { Nothing is explicitly } \\
\text { forbidden. All items } \\
\text { introduced into the } \\
\text { core are subject to } \\
\text { analysis of reactivity } \\
\text { and thermo- } \\
\text { mechanical } \\
\text { performance to } \\
\text { determine if the safety } \\
\text { limits are challenged }\end{array}$ & $\begin{array}{l}\text { Nothing is explicitly } \\
\text { forbidden. All items } \\
\text { introduced into the core } \\
\text { are subject to analysis of } \\
\text { reactivity and thermo- } \\
\text { mechanical performance } \\
\text { to determine if the safety } \\
\text { limits are challenged }\end{array}$ & $<100 g^{235} \mathrm{U}$ & $\begin{array}{l}\text { Yes, depending on } \\
\text { experiment }\end{array}$ & $\begin{array}{l}\text { There is a license limit } \\
\text { for special nuclear } \\
\text { material (SNM) on site }\end{array}$ & $\begin{array}{l}\text { Natural and depleted } \\
\text { uranium can be irradiated. } \\
\text { Enriched uranium } \\
\text { irradiations require a } \\
\text { license amendment }\end{array}$ \\
\hline $\begin{array}{l}\text { Existing flow } \\
\text { loops }\end{array}$ & None & $\begin{array}{l}\text { Independent flow loops } \\
\text { (in-pile tubes) are } \\
\text { installed in } 6 \text { of the } 9 \\
\text { flux traps }\end{array}$ & $\begin{array}{l}1 \text { pressurized water } \\
\text { loop. New loop can be } \\
\text { designed and built to } \\
\text { meet experiment } \\
\text { specifications }\end{array}$ & $\begin{array}{l}\text { No, depending on } \\
\text { experiment }\end{array}$ & $\begin{array}{l}\text { No built-in flow loops. } \\
\text { No restrictions, but } \\
\text { approval of the Reactor } \\
\text { Oversight Committee } \\
\text { might be required }\end{array}$ & $\begin{array}{l}\text { There are no built-in flow } \\
\text { loops, although one can be } \\
\text { installed }\end{array}$ \\
\hline $\begin{array}{l}\text { Existing salt } \\
\text { facility }\end{array}$ & None & No & Yes & $\begin{array}{l}\text { No, depending on } \\
\text { experiment }\end{array}$ & $\begin{array}{l}\text { No built-in salt loops. } \\
\text { No restrictions, but } \\
\text { approval of the Reactor } \\
\text { Oversight Committee } \\
\text { might be required. }\end{array}$ & $\begin{array}{l}\text { There are no built-in salt } \\
\text { loops, although one can be } \\
\text { installed }\end{array}$ \\
\hline $\begin{array}{l}\text { Hot cell } \\
\text { capability }\end{array}$ & $\begin{array}{l}\text { PIE is performed at } \\
\text { two hot cells on the } \\
\text { ORNL campus }\end{array}$ & $\begin{array}{l}\text { Yes, but most PIE is } \\
\text { performed in the Hot } \\
\text { Fuel Examination } \\
\text { Facility (HFEF) or Fuel } \\
\text { Conditioning Facility } \\
\text { (FCF) hot cells at the } \\
\text { Materials and Fuels } \\
\text { Complex nearby. }\end{array}$ & $\begin{array}{l}2 \text { full hot cells and } 1 \\
\text { hot box with } \\
\text { manipulators in reactor } \\
\text { containment building }\end{array}$ & Yes & No & Yes \\
\hline
\end{tabular}


Table 1. Summary of reactor capabilities for a molten salt flowing loop experiment

\begin{tabular}{|c|c|c|c|c|c|c|}
\hline & $\begin{array}{l}\text { High Flux Isotope } \\
\text { Reactor (HFIR) }\end{array}$ & $\begin{array}{c}\text { Advanced Test Reactor } \\
\text { (ATR) }\end{array}$ & MIT Reactor (MITR) & $\begin{array}{c}\text { University of } \\
\text { Missouri Research } \\
\text { Reactor (MURR) }\end{array}$ & $\begin{array}{c}\text { The Ohio State } \\
\text { University Research } \\
\text { Reactor (OSURR) }\end{array}$ & $\begin{array}{c}\text { Penn State Breazeale } \\
\text { Nuclear Reactor }\end{array}$ \\
\hline $\begin{array}{l}\text { Activity } \\
\text { restrictions }\end{array}$ & $\begin{array}{l}\text { See the HFIR Users } \\
\text { Guide }\end{array}$ & $\begin{array}{l}\text { See the ATR Users } \\
\text { Guide }\end{array}$ & $\begin{array}{l}\text { Activity restrictions } \\
\text { are primarily } \\
\text { determined for post- } \\
\text { irradiation } \\
\text { handling. This is } \\
\text { unlikely to be an issue } \\
\text { for fission } \\
\text { chambers/detectors }\end{array}$ & $\begin{array}{l}\text { Determined by Safety } \\
\text { Analysis and Health } \\
\text { Physics }\end{array}$ & $\begin{array}{l}\text { No specific limit for } \\
\text { what is activated using } \\
\text { the reactor, but there are } \\
\text { limitations on the doses } \\
\text { that can be safely } \\
\text { handled }\end{array}$ & Yes, see Users Guide \\
\hline $\begin{array}{l}\text { High } \\
\text { temperature } \\
\text { restrictions }\end{array}$ & $\begin{array}{l}\text { No explicit restriction. } \\
\text { Experiment must pass } \\
\text { safety review }\end{array}$ & $\begin{array}{l}\text { Conditions in the loop } \\
\text { experiments are } \\
\text { independent of the } \\
\text { primary coolant } \\
\text { conditions and are } \\
\text { specified during the } \\
\text { experiment design phase } \\
\text { (negotiations between } \\
\text { User Requirements and } \\
\text { ATR Engineering). For } \\
\text { drop-in capsules } \\
\text { (locations not in the } \\
\text { loops), heating is by } \\
\text { irradiation only; } \\
\text { temperatures are } \\
\text { controlled via capsule } \\
\text { design and regulation of } \\
\text { insulating gas } \\
\text { composition }\end{array}$ & $\begin{array}{l}\text { Heaters are permitted } \\
\text { for in-core and } \\
\text { beamport irradiation } \\
\text { facilities. The heater } \\
\text { can be designed to } \\
\text { meet experiment } \\
\text { requirements }\end{array}$ & $\begin{array}{l}\text { No heaters exist. } \\
\text { Heaters and limits } \\
\text { would depend on the } \\
\text { experiment. }\end{array}$ & $\begin{array}{l}\text { Heaters are permitted, } \\
\text { but none are available } \\
\text { for use. The limit would } \\
\text { be a maximum } \\
\text { temperature on the } \\
\text { facility tube wall }\end{array}$ & $\begin{array}{l}\text { There is no specific limit } \\
\text { on heated experiments. } \\
\text { However, experiments } \\
\text { must be reviewed to } \\
\text { ensure that fuel } \\
\text { temperature limits will not } \\
\text { be exceeded. The } \\
\text { maximum heater power } \\
\text { would be heavily } \\
\text { dependent on experiment } \\
\text { location relative to the fue }\end{array}$ \\
\hline Web link & $\begin{array}{l}\text { https://neutrons.ornl.g } \\
\text { ov/hfir }\end{array}$ & $\begin{array}{l}\text { https://nsuf.inl.gov/Home } \\
\text { /PartnerFacility/652 }\end{array}$ & https://nrl.mit.edu/ & $\begin{array}{l}\text { http://www.murr.miss } \\
\text { ouri.edu/operations.ph } \\
\text { p }\end{array}$ & https://reactor.osu.edu/ & www.rsec.psu.edu \\
\hline
\end{tabular}




\subsection{DEPARTMENT OF ENERGY NATIONAL LABORATORY REACTORS}

The US Department of Energy operates two high-flux research reactors that can serve as the primary test beds for molten salt technology: the High Flux Isotope Reactor and the Advanced Test Reactor. These two reactors are highlighted in the following sections because they offer high flux capabilities, a wide range of experiment sizes, depth of engineering capability, less restrictive limits on activity, and highly capable hot cells.

\subsubsection{High Flux Isotope Reactor}

HFIR is a beryllium-reflected, pressurized, light-water-cooled and moderated flux-trap-type reactor. The core consists of aluminum-clad involute-fuel plates, and the core currently uses highly enriched $235 \mathrm{U}$ fuel at a power level of $85 \mathrm{MW}$. HFIR has an on-stream operating time of about $45 \%$ made up of seven, approximately 25-day, operating cycles per year.

The reactor core, shown in Figure 10, consists of two concentric annular regions, each approximately 61 $\mathrm{cm}$ in height. The flux trap is $\sim 12.7 \mathrm{~cm}$ in diameter, and the outer fueled region is $\sim 43.5 \mathrm{~cm}$ in diameter. The fuel region is surrounded by a beryllium annular reflector approximately $30.5 \mathrm{~cm}$ thick. The beryllium reflector is backed up by a water reflector of effectively infinite thickness. In the axial direction, the reactor is reflected by water. The reactor core assembly is contained in a $2.44 \mathrm{~m}$ diameter pressure vessel which is located in a $5.5 \mathrm{~m}$ diameter cylindrical pool of water. As shown in Figure 11, material and fuel irradiation experiments are typically performed in one of five facility types: flux trap, removable Be (RB*), inner small vertical experimental facility (VXF), outer small VXF, and large VXF.

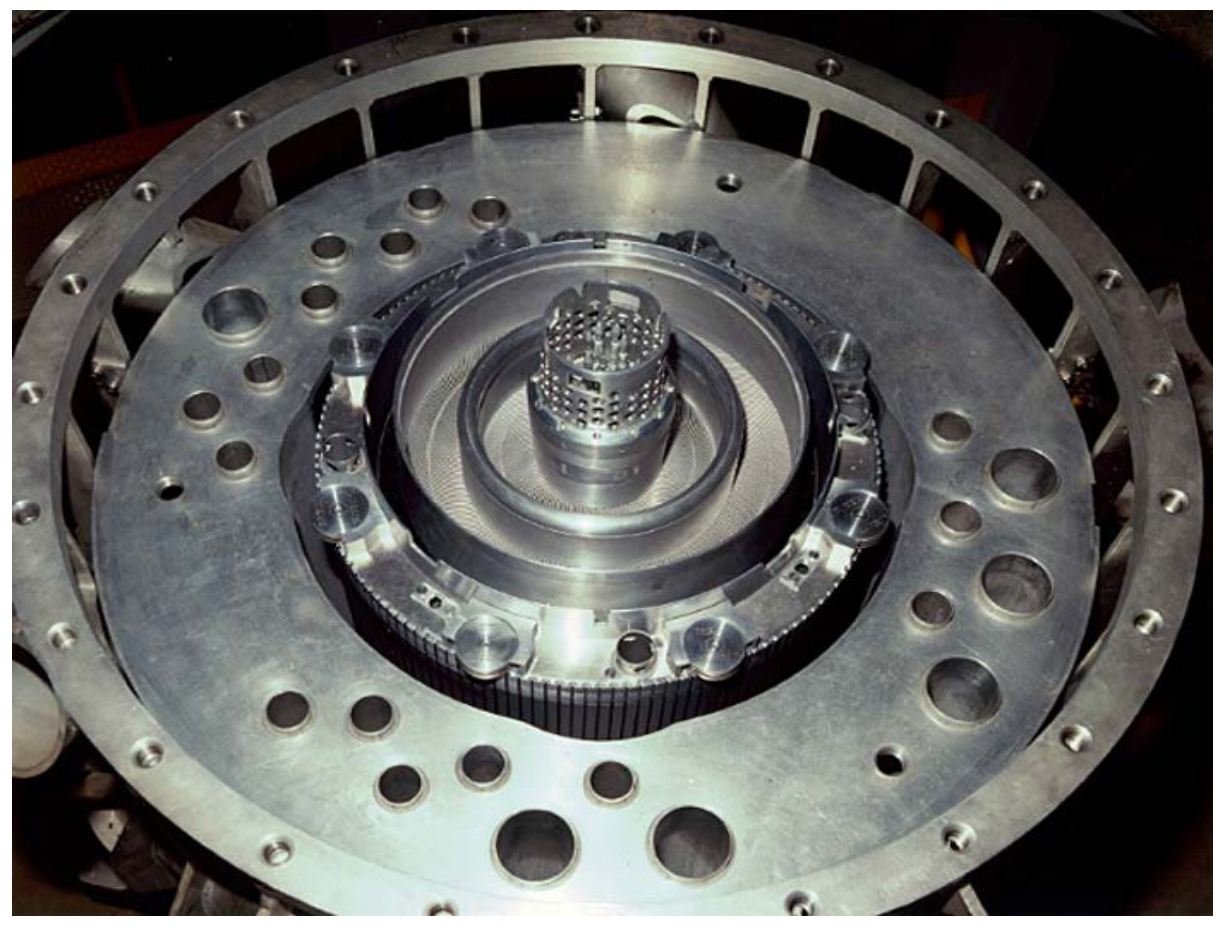

Figure 10. Reactor core fuel plates and primary irradiation facilities. 


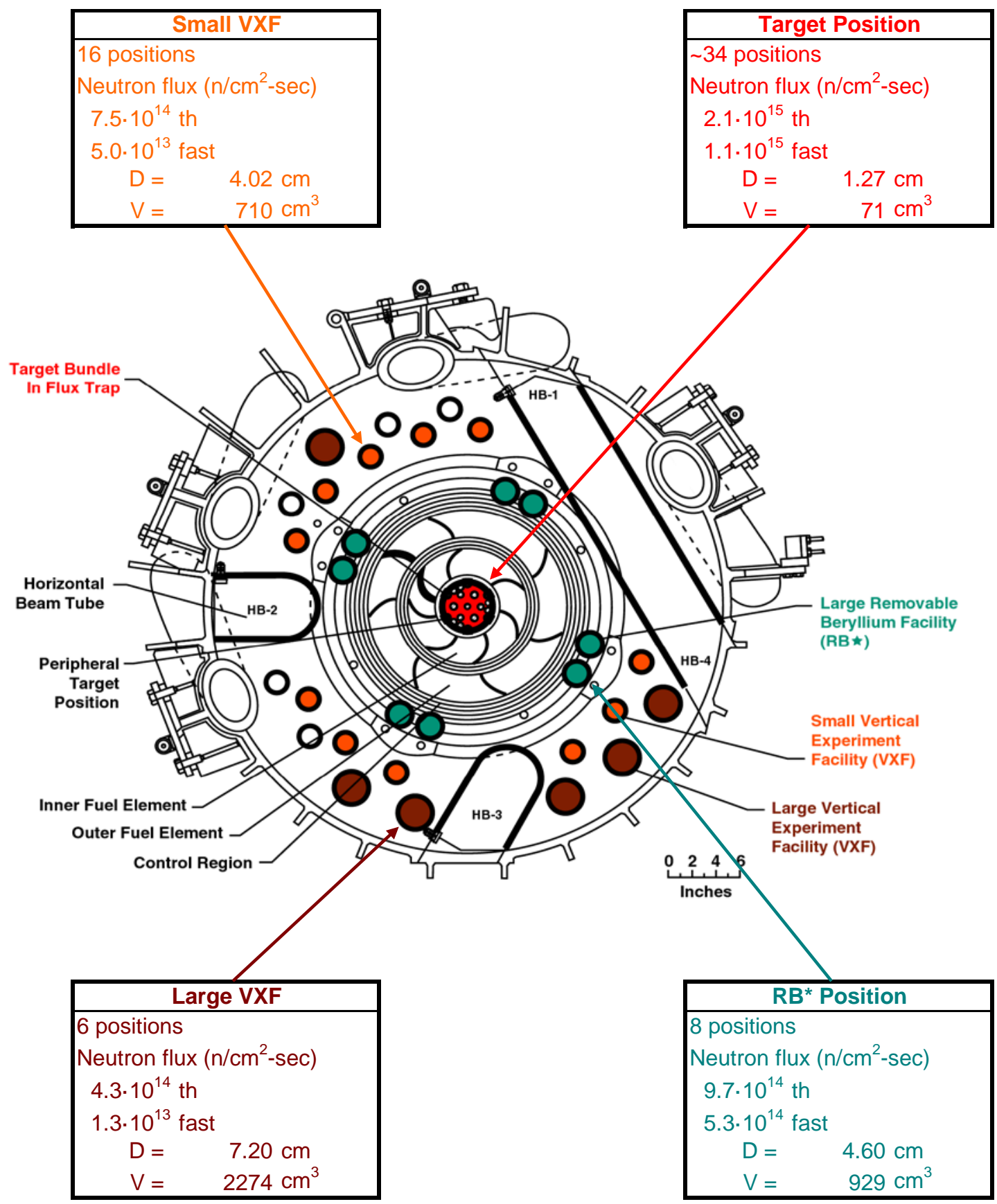

NOTE: Facility diameters and volumes represent total available. Actual specimen volumes will be less.

Figure 11. Characteristics of major irradiation positions in the HFIR.

Experiments operated in the target positions of the center flux trap are typically of small diameter $(\varnothing 1.3 \mathrm{~cm})$ and uninstrumented, although instrumentation is possible in two of the target sites. Most instrumented experiments are operated in the RB* positions (color coded green in Figure 11), where there is relatively easy straight-line access to experiments. There is a long history of operating complex instrumented experiments in the RB* positions, including fueled experiments for the HTGR program, and 
liquid metal containing experiments for the Fusion Materials program. Larger experiments can be accommodated in the large VXF positions.

For a molten salt flowing loop, the RB* and the Large VXF offer the most promising conditions. The $\mathrm{RB}^{*}$ position is more size limited, with an opening diameter of $4.6 \mathrm{~cm}$, but it has the advantage of straight-through access to the reactor's quick opening hatch. This feature allows for good access for utility leads, and it is better supported at the top for seismic concerns. The neutron flux at this position $\left(10^{15} \mathrm{n} / \mathrm{cm}^{2} \cdot \mathrm{s}\right.$ thermal, $5 \cdot 10^{14} \mathrm{n} / \mathrm{cm}^{2} \cdot \mathrm{s}$ fast $)$ is sufficient for almost any reasonable test plan.

The Large VXF position has one distinct advantage: the diameter is $7.2 \mathrm{~cm}$. This makes it very attractive for a flowing loop system. This is a poor position for materials damage studies due to the much lower fast flux. However, the thermal flux of $4 \cdot 10^{14} \mathrm{n} / \mathrm{cm}^{2} \cdot \mathrm{s}$ is still quite high and is more than adequate for tests involving fueled salts where fission or fission product effects are of primary interest. The main drawback to this position is that there is no direct access through the quick opening hatch. A special access tube must be fabricated to guide the utility leads out of the reactor. This has been done many times, but it does require a significantly greater effort by HFIR operators to install and remove the experiment.

\subsubsection{Advanced Test Reactor}

The ATR is a light water-cooled research reactor with a unique serpentine core design that typically operates at $110 \mathrm{MW}$. Because of the core design, the four corner lobes of the core can actually be operated at different powers through the course of a reactor cycle. A cross section of the core is shown in Figure 12.

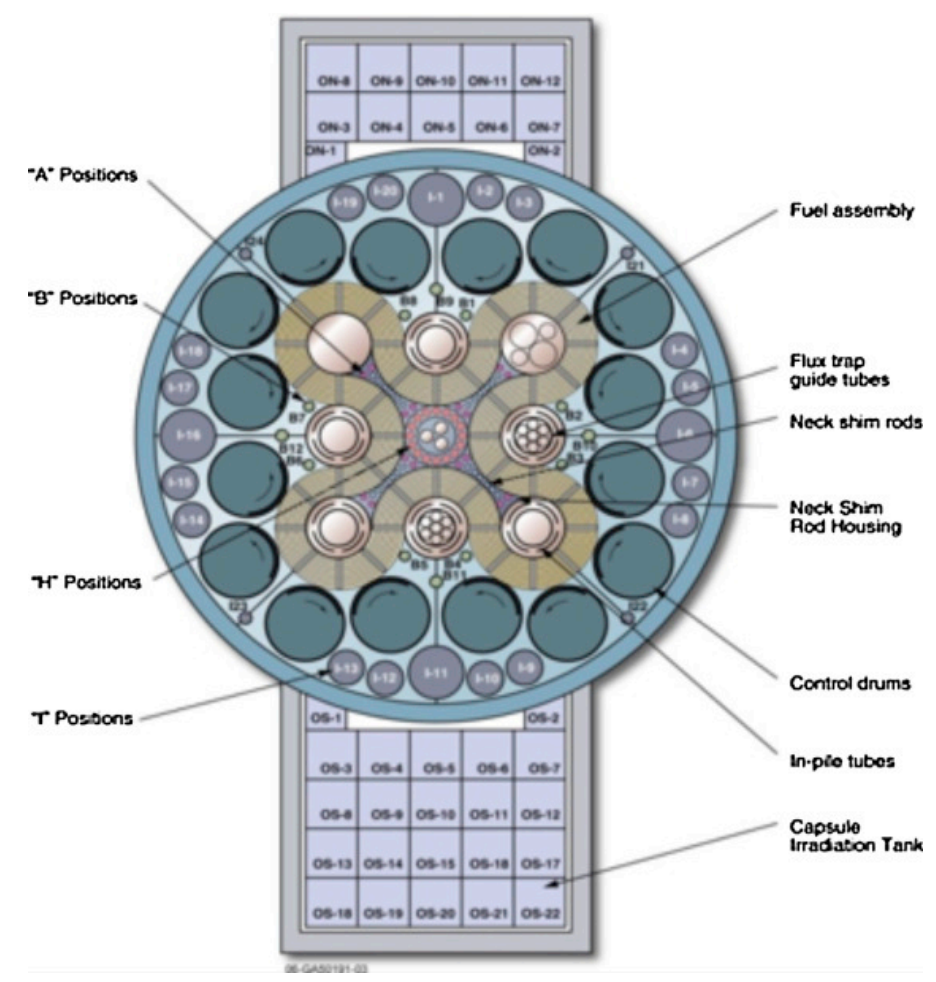

Figure 12. Cross sectional view of the ATR core. 
The primary materials irradiation locations are in the A, B, and I positions. A summary of the size and neutron flux for the various irradiation positions is presented in Table 2.

Table 2. Characteristics of irradiation positions in the ATR

\begin{tabular}{ccccc}
\hline $\begin{array}{c}\text { Irradiation } \\
\text { positions }\end{array}$ & $\begin{array}{c}\text { Diameter } \\
(\mathbf{c m})\end{array}$ & $\begin{array}{c}\text { Thermal flux } \\
\times \mathbf{1 0}^{\mathbf{1 4}} \mathbf{( \mathbf { n } / \mathbf { c m } ^ { 2 } -} \\
\mathbf{s e c})\end{array}$ & $\begin{array}{c}\text { Fast } \\
\mathbf{f l u x} \times \mathbf{1 0}^{\mathbf{1 4}} \\
(\mathbf{n} / \mathbf{c m} \mathbf{2}-\mathbf{s e c})\end{array}$ & $\begin{array}{c}\text { Typical } \\
\text { gamma } \\
\text { heating } \\
\mathbf{W} / \mathbf{g} \text { (SS) }\end{array}$ \\
\hline A-Positions & & & & \\
\hline A-1 to A-8 & 4.04 & 1.9 & 1.7 & 8.8 \\
\hline B-Positions & & & & \\
\hline B-9 to B-12 & 3.81 & 1.1 & 1.6 & \\
\hline I-Positions & & & & \\
\hline Large & 12.70 & 0.17 & 0.012 & \\
Medium & 8.89 & 0.34 & 0.013 & \\
Small & 3.81 & 0.84 & 0.032 & \\
\hline
\end{tabular}

The ATR has an on-stream operating time of about $70 \%$ that is made up of operating cycles that typically range from 6 to 8 weeks of operating time, preceded by an outage of one to two weeks' duration.

The A and B positions are comparable to HFIR's RB* positions, albeit with a slightly smaller diameter and 50\% lower neutron flux. The medium and large I positions offer a distinct advantage in available diameter over any other position in a high-flux reactor, which is advantageous for a flowing loop cartridge experiment. However, both the thermal and fast flux at these large locations are significantly reduced.

\subsection{UNIVERSITY REACTORS}

University reactors should have an important role in the development of molten salt technology, but the available neutron flux in these facilities is usually below that of either HFIR or ATR. The following sections highlight the capabilities of two university reactors with particular interest in salt irradiations.

\subsubsection{The Ohio State University Research Reactor (OSURR)}

The Ohio State University Research Reactor (OSURR) is a pool-type reactor located on the campus of The Ohio State University in Columbus, Ohio. It is licensed to operate at thermal powers up to $0.5 \mathrm{MW}$, with an active fueled length of $38 \mathrm{~cm}$. The OSURR is operated on demand, which makes it ideal for short-term irradiations.

Three irradiation positions are available within the core grid with each consisting of a dry tube that extends from the top of the pool to a position in the core grid. Moveable vertical dry tubes with diameters of $17.8 \mathrm{~cm}$ (7 in.) and $25.4 \mathrm{~cm}$ (10 in.) are available for placing experiments at or near the core boundary. A summary of the size and neutron flux for these irradiation positions is presented in Table 3. 
Table 3. Characteristics of selected irradiation positions in the OSURR

\begin{tabular}{|c|c|c|c|}
\hline Irradiation positions & $\begin{array}{c}\text { Diameter } \\
(\mathbf{c m})\end{array}$ & $\begin{array}{l}\text { Thermal flux } \\
\left(10^{14} \mathrm{n} / \mathrm{cm}^{2} \cdot \mathrm{s}\right)\end{array}$ & $\begin{array}{c}\text { Fast flux (1 MeV Eq.) } \\
\left(10^{14} \mathrm{n} / \mathrm{cm}^{2 \cdot} \mathrm{s}\right)\end{array}$ \\
\hline Central Irrad. Fac. (CIF) & 3.30 & 0.14 & 0.047 \\
\hline Auxiliary Irrad. Fac. (AIF) & 6.22 & 0.045 & 0.026 \\
\hline Peripheral Irrad. Fac. (PIF) & 6.35 & 0.031 & 0.012 \\
\hline 7-inch moveable dry tube & 16.51 & 0.011 & 0.02 \\
\hline
\end{tabular}

The large-diameter facilities in OSURR allow for larger scale experiments, which is an advantage for flowing loop tests. The relatively low neutron flux is not conducive to high fluence experiments, but it may be an ideal test bed for testing cartridge loop technology in a facility with easier access than that of a national laboratory. OSURR can accept fueled salt, but the post-irradiation handling limits may restrict the fuel loading and burnup to relatively low levels.

\subsubsection{Massachusetts Institute of Technology Reactor}

MITR is a $6 \mathrm{MW}$ light-water cooled and moderated research reactor operated by the Massachusetts Institute of Technology in Cambridge, Massachusetts. A cross section of the MITR core is shown in Figure 13.

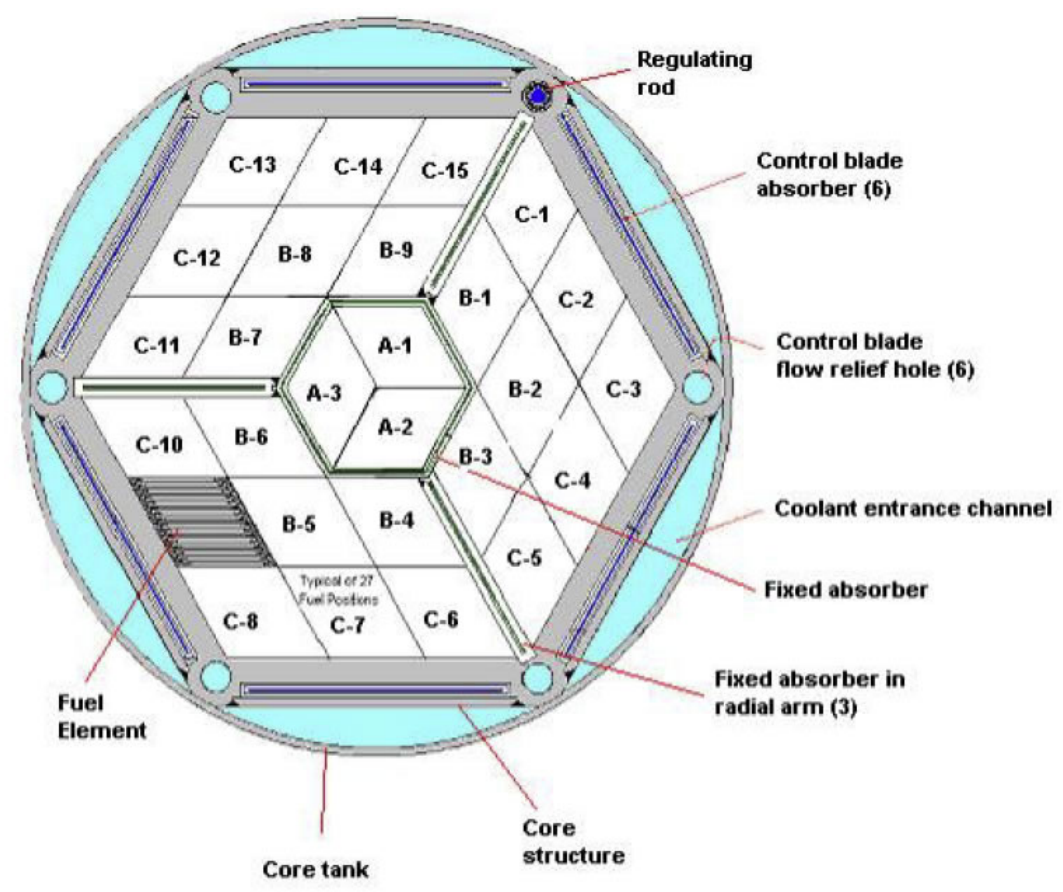

Figure 13. Cross section view of the MITR core.

There are three in-core irradiation positions located in the center of the core in the A-1, A-2, and A-3 positions. An additional irradiation position exists in the graphite reflector (the 3GV facility). Characteristics of the MITR irradiation positions are presented in Table 4. 
Table 4. Characteristics of irradiation positions in the MITR

\begin{tabular}{|c|c|c|c|}
\hline Irradiation positions & $\begin{array}{l}\text { Diameter } \\
(\mathbf{c m})\end{array}$ & $\begin{array}{l}\text { Thermal flux } \\
\left(10^{14} \mathrm{n} / \mathrm{cm}^{2} \cdot \mathrm{s}\right)\end{array}$ & $\begin{array}{c}\text { Fast flux (1 MeV Eq.) } \\
\left(10^{14} \mathrm{n} / \mathrm{cm}^{2} \cdot \mathrm{s}\right)\end{array}$ \\
\hline In-core (3 are available) & 4.57 & 0.36 & 1.2 \\
\hline Graphite reflector (3GV) & 7.62 & $0.04-0.1$ & --- \\
\hline
\end{tabular}

A series of molten salt experiments have been conducted in the in-core position where measurements of corrosion and tritium transport were made on $\mathrm{SiC} / \mathrm{SiC}$, and metal coupons were irradiated in liquid lithium fluoride-beryllium fluoride salt for the High Temperature Fluoride Salt Reactor.

\section{SUMMARY AND CONCLUSIONS}

Irradiation testing can and should include a wide variety of experimental facilities, including static capsules, natural convection loops, and pumped loops under low and high flux conditions. This document outlines existing and future capabilities for the most challenging subset of these experimental conditions: irradiation testing in a flowing loop under a high neutron flux.

Under both design and safety-basis conditions, the primary containment and all components internal to the containment should (1) be resistant to salt corrosion, (2) maintain adequate strength under anticipated and off-normal conditions, and (3) be resistant to corrosion induced by entrained fission products. The levels of resistance and strength can only be determined by the reactor design authority, but these basic issues must be addressed, and while much can be learned from out-of-pile testing, many of these concerns can only be addressed with irradiation testing.

A flowing loop design can be accomplished with an external flow loop, which extends from the reactor core out to an adjacent facility for pumping and heat exchange, or a cartridge loop, in which the entire experiment is self-contained, and the reactor's coolant provides the ultimate heat sink. There are advantages and disadvantages to either approach, but the challenges associated with uniformly melting salt and keeping it molten throughout the irradiation period strongly favor a cartridge-type experiment.

This document outlines several key aspects that must be considered in a flowing loop design. Some of these design features are common to all instrumented experiments, but some are unique to molten salt. Two challenges stand out: (1) the inability to use organic engineering materials such as o-rings to create seals between moving parts, and (2) the lack of a commercially available molten salt pump that is small enough to fit inside a cartridge experiment and that does not use o-ring seals.

Fortunately, there is a history of molten salt flow loop experiments in the United States, and many of these problems are not new. A series of flowing loop experiments were reviewed, and the literature has been summarized. Two important considerations result from this literature review. First, there were many failures, unexpected leaks, and surprise results during this earlier irradiation campaign. As the current irradiation campaign begins, a new generation of tests, further challenges, and surprises should be expected. Second, the earlier campaign spent a tremendous sustained effort to develop a viable molten salt pump. It is clear from their work that this should be a priority in the current campaign for a reactorscale pump and a miniature-scale pump that could be used in cartridge irradiation experiments.

Several US reactors were identified as potential neutron sources for future salt experiments. The two national laboratory reactors, HFIR and ATR, are the most interesting because of their high flux 
capabilities, wide range of experiment sizes, depth of engineering capability, less restrictive limits on activity, and highly capable hot cells. However, there is a place for university reactors as well, especially in the development and testing phase of these experimental assemblies. 


\section{REFERENCES}

1. A. E. Wright, J.P.B., N. J. Carson, C. E. Dickerman, J. B. Heineman, A. E. Klickman, R. A. Noland, R. J. Page, L.E. Robinson, and J. P. Tylka. MARK-III Integral Sodium Loop for LMFBR Safety Experiments in TREAT. in Conference on Fast, Thermal, and Fusion Reactor Experiments in TREAT. 1982. Salt Lake City, Utah, USA.

2. Jordan, W.H.d., Aircraft Nuclear Propulsion Project Quarterly Progress Report for Period Ending June 10, 1955. 1955, Oak Ridge National Laboratory: Oak Ridge National Laboratory.

3. Jordan, W.H.d., Aircraft Nuclear Propulsion Project Quarterly Progress Report for Period Ending December 31, 1956. 1956, Oak Ridge National Laboratory: Oak Ridge National Laboratory.

4. $\quad$ Conlin, J.A., MSPR In-Pile Loop ORNL-MTR-44 Design and Operating Conditions. 1958, Oak Ridge National Laboratory: Oak Ridge National Laboratory.

5. Trauger, D.B., and Conlin Jr., J.A., Circulating Fused-Salt Fuel Irradiation Test Loop. Nuclear Science and Engineering, 1961. 9: p. 346-356.

6. Trauger, D.B., Some Major Fuel-Irradiation Test Facilities of the Oak Ridge National Laboratory. 1964, Oak Ridge National Laboratory: Oak Ridge National Laboratory.

7. Savage, H.C., Compere, E.L., Baker, J.M., and Bohlmann, E.G., Operation of Molten-Salt Convection Loops in the ORR, R. Chemistry, Editor. 1967: Oak Ridge National Laboratory. 